LA- - $10188-M S$

DE85 005598

\title{
Groundwater Chemistry Along Flow Paths Between a Proposed Repository Site and the Accessible Environment
}

\author{
A. E. Ogard \\ J. F. Kerrisk
}

$\because a+$ cesn reproduced from the fest inchingle copy to permit the hreadast fisistite evallability. 


\section{DISCLAIMER}

This report was prepared as an account of work sponsored by an agensy of the United States Government. Neither the United States Government nor any agency thereof, nor any of their employees, makes any warranty, express or implied, or assumes any legal liability or responsibility for the accuracy, completeness, or usefulness of any information, apparatus, product, or process disclosed, or represents that its use would not infringe privately owned rights. Reference herein to any specific commercial product, process, or service by trade neme, trademark, manufacturer, or otherwise does not necessarily constitute or imply its endorsement, recommendation, or favoring by the United States Government or any agency thereof. The views and opinions of authors expressed herein do not necessarily state or reflect those of the United States Government or any agency thereof. 


\title{
GROUNDWATER CHEMISTRY ALONG FLOW PATHS BETHEEN A PROPOSED REPOSITORY SITE AND THE ACCESSIBLE ENVIRONMENT
}

by

A. E. Ogard and J. F. Kerrisk

\begin{abstract}
The Nevada Nuclear Waste Storage Investigations Program of the Department of Energy is investigating Yucca Mountain in the Nevada Test Site as a possible repository location. As part of this investigation, the groundwater from all pumped wells in and near the site has been sampled and analyzed; the results are reported in this document. The speciation and solubility of nuclear waste elements in these groundwaters have been calculated using the EQ3/6 computer code. Estimates have also been made of the $\mathrm{pH}$ and Eh buffering capacity of the water/rock system of Yucca Mountain.
\end{abstract}

\section{INTRODUCTION}

The Department of Energy, through the Nevada Nuclear Waste Storage Investigations (NNWSI) program, is characterizing a site in southwestern Nevada as a possible location for a high-level nuclear waste repository. The site, at Yucca Mountain, is located on the southwestern edge of the Nevada Test Site (NTS) and on adjacent US Bureau of Land Management land as well as land controlled by the US Atr Force (see Fig. 1). The Topopah Spring Member tuff in the unsaturated zone of Yucca Mountain has been selected as the site for the proposed repository. The most likely mechanism by which waste elements could be released from the repository into the accessible environment is by transport in water that passes through the repository and along flow paths to the biosphere. Los Alamos National Laboratory is studying groundwater chemistry along potential flow paths from the repository. 


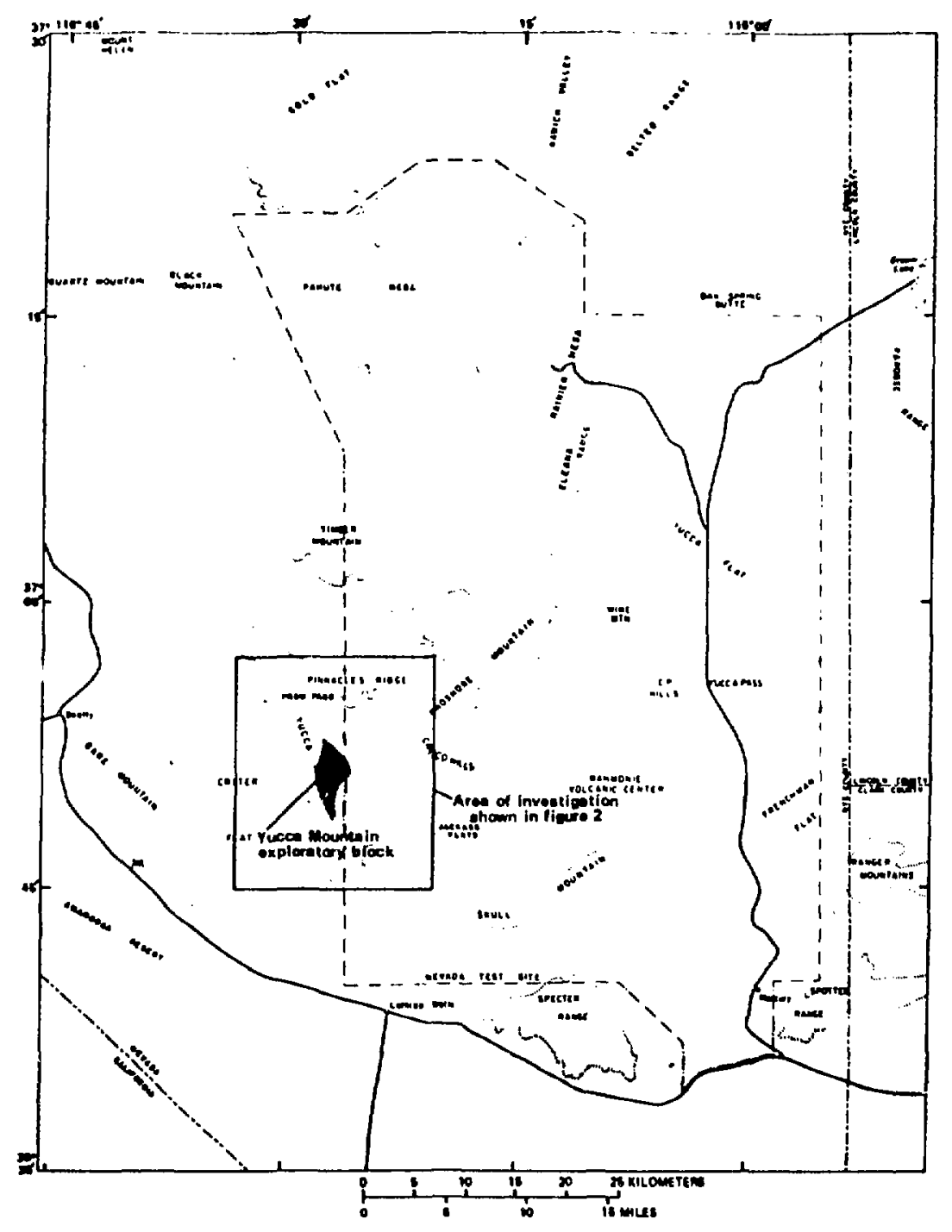

Fig. 1. Map of the NTS and vicinity showing the area of investigation and the Yucca Mountain exploratory block (from Ref, 1). 
Chemistry of the groundwater is important because the quantity of waste elements transported in the water will depend on waste-element solubility, speciation, and sorption on the minerals encountered--all of which depend on water chemistry. The Nuclear Hydrology Division of the US Geological Survey (USGS), in another portion of the NNWSI program, is sicudying water movement In the unsaturated and saturated zones around Yucca Mountain to Identify flow paths to the accessible environment.

The proposed repository site, in the Topopah Spring Member tuff, is at a depth of 300 m or more below the surface of Yucca Mountain. In addition to portions of the densely welded, devitrified tuff of the Topopah Spring Member that are beneath the repository, tro other unsaturated tuff strata, the nonwelded tuffs of Calico Hills and the Prow Pass Member of the Crater Flat tuff, are between the repository location and the stat1 = water level. The Bullfrog and Tram Members are two additional untis of the Crater Flat tuff in the saturated zone beneath the repository site. These two units are discussed later with respect to well-pumping tests. Although the tuffs of Calico Hills and the Prow Pass Member are unsaturated beneath the repository site, these strata dip below the static water level to the east. of Yucca Mountain. Both units are highly zeolitized where they are near saturation, that is, below the static water level or just above, where capillary action has increased the saturation level.

The most likely mechanism for a release of waste elements to the environment is through waste-element dissolution from the snlid waste form stored in a repository and transport in water. At this time, uSGS models of water transport indicate that water from the repository w111 move downward through the unsaturated zone and into groundwater in the saturated zone. The specific pathways of groundwater travel in the saturated zoise are still uncertain. Based on this assessment of flow paths, it is clear that water chemistry in both the unsaturated and saturated zones is important. Pore water from the unsaturated zone has not been sampled as yet, but samples will be taken during construction of the Exploratory Shaft. Thus, Information about the chemistry of unsaturated-zone water is available only by analogy with water from similar areas or by chemical modeling. Groundwater from the saturated zone has been sampled from a number of deep wells in the vicinity 
of the Yucca Mountain site. Water from these wells has been studied extensively and has provided essentially all the information presented in this report.

Waste-element transport in groundwater is a slow process, so slow that direct experimental verification of repository performance is not possible. Instead, performance-assessment calculations will estimate the rates and quantities of waste elements transported from the repository to the accessible environment. These alalyses will employ water-chemistry data in a number of ways.

(1) The concentrations of waste elements dissolved in groundwater will directly influence waste-element transport. Waste-element concentrations can be calculated from (a) groundwater composition; (b) thermodynamic data for the waste elements, components of the groundwater, and local minerals; and (c) appropriate models such as the EQ3/6 computer program.

(2) Waste elements are transported not only as dissolved species, but also as colloids or particulates, or they can be adsorbed on natural particulates in the water. Although transport of particulate material is primarily a physical process, groundwater chemistry will influence the formation and stability of waste-element colloids and particulates and the sorption on natural particulates. The formation of waste-element colloids and particulates is being studied in other areas of the NNWSI program. Characterization of natural particulates (size, quantity, and composition) in Yucca Mountain water is just beginning. Unfortunately, particulates can only be collected by pumping, which creates unnatural, induced-flow conditions. Particulate concentrations determined from pumped wells should be conservative, however, because they should be higher than concentrations under slower, more natural flow conditions. A few preliminary filtration experiments have shown some tuff particles in pumped well water. These measurements have not yet been quantified. (Particulate transport will not be considered further in this report.)

(3) Groundwater chemistry will vary as a function of time and location along the flow paths. It is necessary not only to know present groundwater chemistry, it must also be predicted for the future to complete performance-assessment calculatbons that cover time spans of 
10000 years or more. Groundwater composition is a function of the mineralogy through which the water is flowing, the atmosphere over the land mass, and the biota on the land mass at recharge areas. Models of groundwater chemistry can be used in conjunction with data about these items to estimate variations of groundwater chemistry with time. The $\mathrm{pH}$ and Eh buffering capacity of groundwater are particularly important.

(4) Knowledge of the vertical and lateral varlations of groundwater composition at Yucca Mountain can aid in modeling local hydrology. However, determination of groundwater flow paths is the responsibility of the USGS, and no interpretation of our data as it pertains to flow path is made in this report. It is clear that the physical and chemiciti characteristics of the water system must ultimately form a consistent picture that can be used in the performance-assessment calculations.

The remainder of this report discusses the groundwater-chemistry data collected to date from wells in the vicinity of Yucca Mouniain and from a few wells in adjacent areas that add to our understanding of the Yucca Mountain data. Information needed for performance assessment will be calculated from these data. This report is divided into sections that discuss (1) the experimental procedures for sampling and analysing the water; (2) the water compositions determined; (3) the implications of the data for spactal and temporal variations in water chemistry, speciation and solubility, $\mathrm{pH}$ buffering capacity, and redox buffering capacity; and (4) conclusions and proposals for future work.

\section{EXPERIMENTAL PROCEDURES}

In the vicinity of the repository site, a number of deep wells have been drilled and pumped (Fig. 2). Information on construction, pumping, and testing of these wells can be obtained from Benson et al. ${ }^{1}$ and from USGS open File reports that have been compiled for each of the individual wells. ${ }^{2-6}$

Three different approaches were used by Los Alamos to obtain samples of groundwater from wells drilled by the USGS into the saturated zone in the vicinity of Yucca Mountain. 


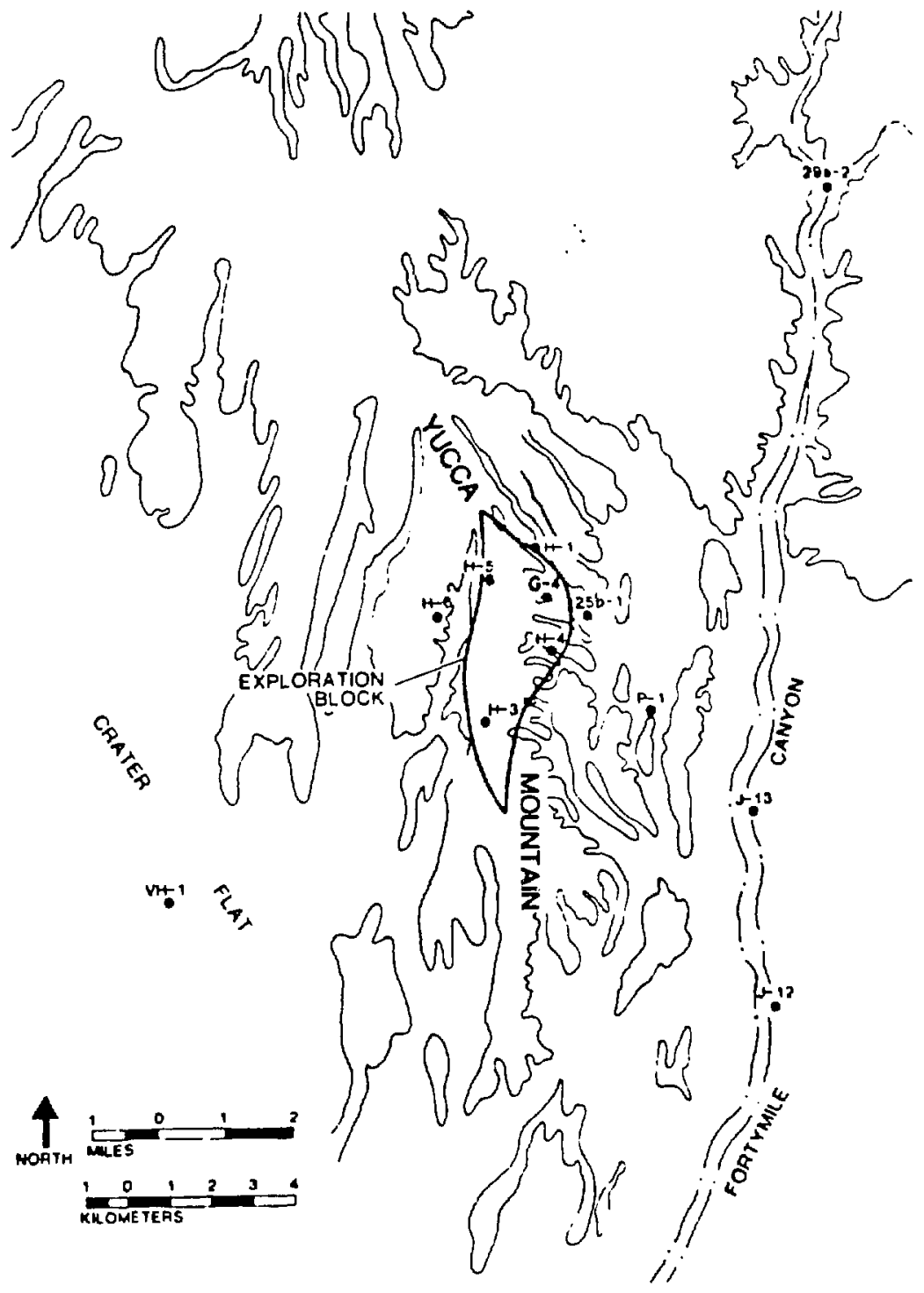

Fig. 2. Selected drill-hole locations on and near the Yucca Mountain exploration block. (The names of the wells have been shortened for clarity; for example, USW $\mathrm{H}-6$ is 1 isted as $\mathrm{H}-6$ and $\mathrm{UE}-25 \mathrm{p} \equiv 1$ as $\mathrm{P}-1$, etc.) 
(1) Samples were taken aerobically and sometimes anaerobically during the USGS's pumping tests. The tests yielded integral samples because all the producing zones of the well contributed to the groundwater that was sampled. These samples are inexpensive to obtain; they are taken soon after other tests (such as the tracejector tests), and very 1ittle extra drill rig and crew time is needed. Unfortunately, the sample is a composite sample from all the producing zones of the well, and the well may not have been pumped.long enough to clear the well of drilling fluids. (A detergent-free water is termed formation water.)

(2) Individual permeable zones were isolated by inflatable packers and the water from between these packers was pumped and sampled. The pumpings of UE-25b非 1 and USW H-3 ai:e examples of this method (see Refs. 7 and 8 , respectively). These tests provide the best information on the change in groundwatar composition with depth because the isolation of individual permeable zones yields water from a particular depth rather than an integral sample from all depths. The values of Eh measured from the two wells also provide the best estimates of water Eh at depth because measurements were made on water from an isolated zone and without exposing the samples to air. The tests in Yucca Mountain, however, are very expensive because of the deep water table and long pumping times required to clear the waters of drilling fluids.

(3) Individual samples were taken from selected depths in static holes by lowering an evacuated stainless steel bottle to a selected depth, opening the valve electrically to allow the bottle to fill, closing the valve, and raising the bottle to the surface, after which the sample was shipped to Los Alamos for analysis. (Additional details can be found in Refs. 9 and 10.) These so-called "thief" samples are easy to obtain in static wells and are relatively cheap. However, it has not been established whether or not the results are representative of water that is in equilibrium with the particular zone sampled.

The composition of the groundwater was determined by analysis for dissolved cations and anions, by electrode measurements for Eh, pH, sulfide, and dissolved oxygen, by alkalinity titrations, and by analysis for detergents. 
Cation concentrations (for calcium, magnesium, sodium, potassium, lithium, iron, manganese, aluminum, and silicon) were determined using a Beckmann SpectraScan IIIB Multielement Emission Spectrometer with a DC Plasma Excitation Source. The groundwaters were normally filtered through a $0.05-\mu m$ Nuclepore membrane under anaerobic conditions at the well head, then acidified with ultrapure $\mathrm{HNO}_{3}$, and finally sent back to Los Alamos for this analysis.

The anion concentrations of the groundwater were determined using a Dionex Model 16 Ion Chromatograph in the mobile laboratory at the well site. This instrument proved to be extremely durable and dependable for field operations. Samples of anaerobically filtered water, water taken directly from the well, and water exiting the mobile laboratory were all used as samples for anion analysis. Varying the sampling procedures did not produce any discernable differences in the samples' anion content.

Alkalinity was determined by using a Metrohm E636 Titroprocessor to titrate unfiltered samples with hydrochloric acid. The detergent content of the water was determined spectrophotometrically with a Hach Model DR-EL/4 Portable Laboratory. Detergent was a good indicator or tracer of drilling fluids in the well. The Eh was measured with a Sensorex S500C-ORP electrode, phi with an Orion "Ross" Mode1 81-02 combination electrode, sulfide with a Beckman \#39610 Sulfide/Silver Electrode, and oxygen with a Yellow Springs Instrument Model 54 ARC dissolved-oxygen meter and electrode.

Detailed Los Alamos procedures are to be published in a Los Alamos Quality Assurance (QA) document. 11 Additional information can be found in earlier Los Alamos reports. $7-10,12-15$

\section{RESULTS}

The analyses of groundwaters from the pumped wells are grouped and listed in Tables I through IV. The difference between Tables I/II and III/IV is in the units of the data; Tables I and II use mg/ $\ell$ to express concentration, whereas mols/ $\ell$ is used in Tables III and IV. Techniques used in sampling the groundwaters listed here were either integral sampling (Wells USW VH-1, H-6, H-5, G-4, H-1, H-4, and J-13, UE-29a作, J-12, the paleozoic aquifer of UE-25p\#1, and parts of Well UE-25b\#1) or sampling from individual packed off zones (Wells UE-25b非 1 and USW H-3). In these tables, the wells 
TABLE I

ELEMENTAL CONCENTRATIONS IN GROUNDWATERS

FROM THE VICLNITY OF YUCCA MOUNTAIN

\begin{tabular}{|c|c|c|c|c|c|c|c|c|c|c|}
\hline \multirow[b]{2}{*}{ We11 } & \multirow{2}{*}{$\begin{array}{l}\text { Field } \\
\mathrm{pH} \\
\end{array}$} & \multicolumn{9}{|c|}{$\begin{array}{l}\text { Concentration } \\
(\mathrm{mg} / \mathrm{l})\end{array}$} \\
\hline & & $\mathrm{Ca}$ & $\mathrm{Mg}$ & $\mathrm{Na}$ & $\mathrm{K}$ & $\mathrm{LI}$ & $\mathrm{Fe}$ & $\mathrm{Mn}$ & AI & $\mathrm{Si}$ \\
\hline USW $V H-1^{b}$ & 7.5 & 10 & 1.5 & 80 & 1.9 & 0.090 & & & & 23 \\
\hline USW $H-6$ & 7.4 & 5.5 & 0.22 & 74 & 2.1 & 0.10 & 0.12 & 0.04 & 0.12 & 20.0 \\
\hline USW $\mathrm{H}-3$ & 9.4 & .7 .8 & 0.01 & 124 & 1.5 & 0.22 & 0.13 & 0.01 & 0.51 & 16.9 \\
\hline USW $\mathrm{H}-5$ & 7.1 & 1.1 & 0.03 & 54 & 2.3 & 0.04 & 0.01 & N.D. & 0.17 & 17.4 \\
\hline USW G-4 & 7.1 & 9.2 & 0.15 & 56 & 2.5 & 0.08 & 0.04 & 0.02 & 0.02 & 19.6 \\
\hline USW $\mathrm{H}-1$ & 7.5 & 6.2 & $<0.1$ & 51 & 1.6 & 0.04 & & & & 19 \\
\hline USW $\mathrm{H}-4$ & 7.4 & 10.8 & 0.19 & 84 & 2.6 & 0.16 & 0.03 & 0.005 & 0.04 & 25.9 \\
\hline $\mathrm{UE}-25 \mathrm{~b} \# 1^{\mathrm{C}}$ & 7.7 & 19.7 & 0.68 & 56 & 3.3 & 0.28 & 0.04 & 0.004 & 0.03 & 31.5 \\
\hline$U E-25 b \# 1^{d}$ & 7.2 & 18.4 & 0.68 & 46 & 2.5 & 0.30 & 0.69 & 0.36 & 0.04 & 28.7 \\
\hline $\mathrm{UE}-25 \mathrm{~b} \equiv 1^{\mathrm{e}}$ & 7.3 & 17.9 & 0.66 & 37 & 3.0 & 0.17 & 0.08 & 0.07 & 0.06 & 28.8 \\
\hline$J-13$ & 6.9 & 11.5 & 1.76 & 45 & 5.3 & 0.06 & 0.04 & 0.001 & 0.03 & 30.0 \\
\hline UE-29a非 & 7.0 & 11.1 & 0.34 & 51 & 1.2 & 0.10 & 0.05 & 0.03 & 0.04 & 25.8 \\
\hline$J-12^{b}$ & 7.1 & 14 & 2.1 & 38 & 5.1 & & & & & 25 \\
\hline UE $-25 p$ 非 1 & 6.7 & 87.8 & 31.9 & 171 & 13.4 & 0.32 & $<0.1$ & $<0.1$ & 0.1 & 30 \\
\hline
\end{tabular}

a Ionic or molecular spectes are not listed; concentration is based on the element.

bata from L. ' 'son et al. 1

CIntegral water sample.

d Bullfrog zone, 4th day.

e Bullfrog zone, 28th day. 
TABLE II

ANION CONCENTRATIONS AND OTHER MEASUREMENTS

FOR GROUNDWATERS FRGM THE VICINITY OF YUCCA MOUNTAIN

Concentration

$(\mathrm{mg} / \ell)$

Wel1 $\quad \mathrm{F}^{-} \mathrm{Cl}^{-} \mathrm{SO}_{4}^{2-} \quad \mathrm{HCO}_{3}^{-} \quad \mathrm{NO}_{2}^{-} \quad \mathrm{NO}_{3}^{-} \quad \mathrm{O}_{2}$ Detergent $\mathrm{Eh}^{\mathrm{a}}$

USW VH-1 V $^{\mathrm{b}} \quad 2.7 \quad 10 \quad 45 \quad 165$

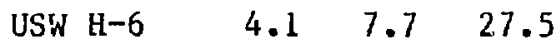

N.D. $5.3 \quad 5.6$

UISW H-3 $\quad 5.4 \quad 8.3 \quad 31.2$

$<0.10 \quad 0.2<0.1 \quad<0.02 \quad-143$

USW H-5 $\quad 1.3 \quad 5.7 \quad 14.6$

N.D. $8.6 \quad 6.3 \quad<0.005 \quad 353$

$\begin{array}{llll}\text { USW G-4 } & 2.4 & 5.5 & 15.7\end{array}$

N.D. $\quad 5.5 \quad 6.4$

402

USW $\mathrm{H}_{-1}^{\mathrm{b}} \quad 1.0 \quad 5.8 \quad 19 \quad 122$

USW $\mathrm{H}-4 \quad 4.5 \quad 6.2 \quad 23.9$

N.D. $\begin{array}{llll}4.7 & 5.8 & >2 & 216\end{array}$

$\begin{array}{llll}U E-25 b \text { \# l }^{d} & 1.2 & 7.1 & 20.6\end{array}$

N.D. $0.6 \quad 1.8$

220

$\begin{array}{llll}\text { UE }-25 b_{k 1}{ }^{\mathrm{e}} & 1.5 & 9.8 & 21.0\end{array}$

$0.5 \quad 2.2<0.1$

2.7

$-18$

$\begin{array}{llll}\mathrm{UE}-25 \mathrm{~b} \# 1^{\hat{\mathrm{f}}} & 1.2 & 6.6 & 20.3\end{array}$

N.D. $4.5 \quad 1.8$

0.02

160

$\mathrm{J}-13$

$2.1 \quad 6.4 \quad 18.1$

N.D. 10.

5.7

N.D.

UE-29a非 2

$\begin{array}{lll}0.56 & 8.3 & 22.7\end{array}$

N.D. $18.7 \quad 5.7$

305

$\mathrm{J}-12^{\mathrm{b}}$

$2.1 \quad 7.322$

119

UE $-25 p$ 非

$3.5 \quad 37$

129

N.D. $<0.1$

$<0.2$

360

$a_{\mathrm{mV}}$ vs $\mathrm{H}_{2}$ electrode.

$b_{\text {Data from L. Benson et al. }}{ }^{1}$

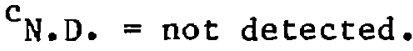

dirtegral water sample.

$e_{\text {Bu11frog zone, 4th day. }}$

$f_{\text {Bullfrog zone, 28th day. }}$ 
TABLE III

EIEMENTAL CONCENTRATIONS IN GROUNDWATER

EROM THE VICINITY OF YUCCA MOUNTAIN

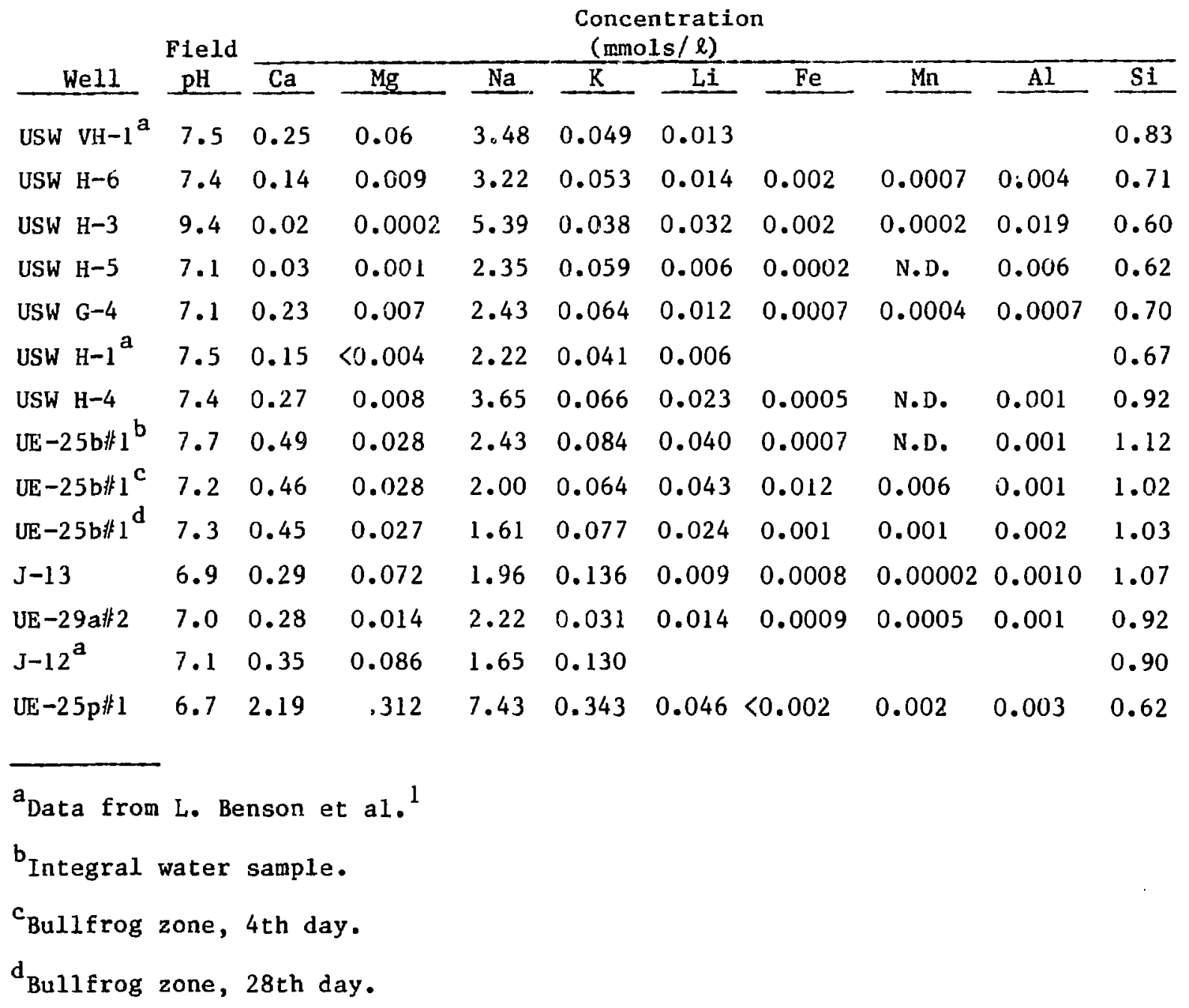


TABLE IV

ALKALINITY AND ANION CONCENTRATIONS IN GROUNDWATER

FROM THE VICINITY OF YUCCA MOUNTAIN

Concentrations

(mmols/ $/ \ell$ )

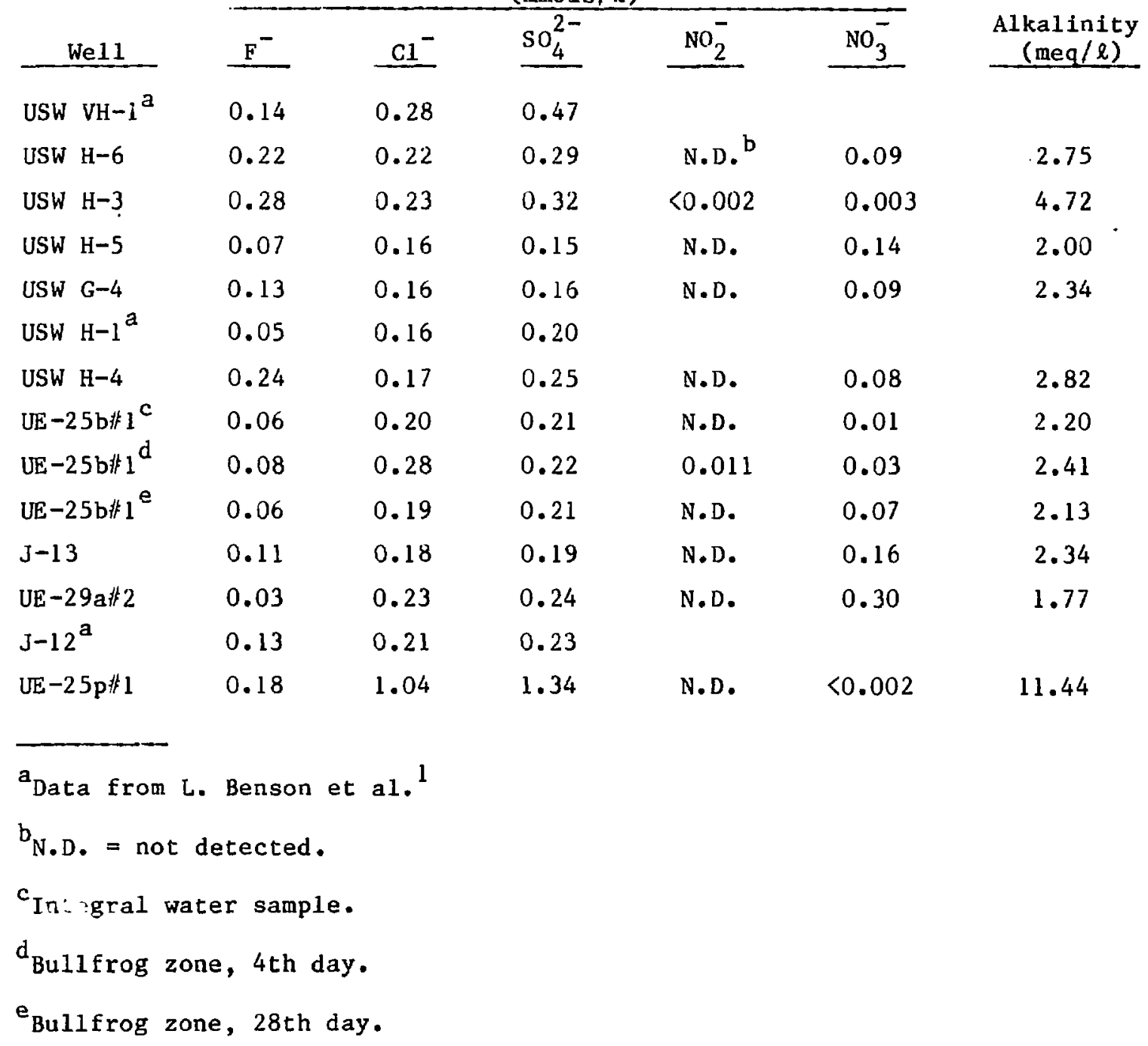


are generally arranged in the order of their location, from west to east--the direction of downward slope of the stratigraphy. The altitudes of this sloping stratigraphy can vary because of faulting and thrusting.

The in situ organic content of the waters from Wells UE-25b非 and $J-13$ was measured by $\mathrm{J}$. Means of Battelle Columbus. ${ }^{16}$ Total organic carbon contents were $0.15 \mathrm{mg} / \ell$ in We11 J-13 water and $0.55 \mathrm{mg} / \ell$ in Well UE-25b非 1 water, respectively. The lower carbon content in $\mathrm{J}-13$ water is prosably representative of the in situ content because this is a producing well for the NTS and all drilling fluids have been removed by extensive pumping.

"Thief" sampling results for Wells USW $\mathrm{H}-1$ and USW $\mathrm{H}-4$ waters are presented in Tables $\mathrm{V}$ and VI.

\section{DISCUSSION}

\section{A. Unsaturated Zone}

Although we do not have pore water samples from the unsaturated zone for analyses, estimates can be made of the pore water composition from the work of White et al. ${ }^{17}$ Water in contact with devitrified tuff has higher relative calcium contents than water in contact with vitric tuffs.

(1) Pore water in equilibrium with the devitrified Topopah Spring Member tuffs will be higher in relative calcium content and lower in relative sodium content than the waters described in Tables I through IV; calcium may be as high as 65 relative mole percent. Duffy, ${ }^{14}$ in preliminary experiments with distilled water flowing through Topopah Spring Member tuff, found relative mole percentages of calcium (16), sodium (52), and potassium (32). In Fig. 3, relative calcium, sodium, and potassium compositions for groundwaters below or near Yucca Mountain are plotted; pore water compositions should appear at the botton of the figure. The Eh will be oxidizing $(\nu+400 \mathrm{mV}$ ) because the fractured structure of the Topopah Spring Member tuff should allow oxygen to penetrate throughout this zone. The $\mathrm{HCO}_{3}^{-}$content should be less than that of most wel1 waters listed in Tables I through IV because there are fewer organics in the soil cover at the lower altitude of Yucca Mountain than at the higher recharge areas of Pahute Mesa. 
TABLE V

COMPOS ITIONS OF GROUNDHATERS FROM

YUCCA MOUNTAIN WELLS

"THIEF" SAMPLES

Well and

Depth

(m)

USW $\mathrm{H}-1$

610

7.2

3.5

0.20

106

$6.4 \quad 0.07$

0.02

0.1

0.08

0.04

0.15

$\begin{array}{llll}7.0 & 5.2 & 0.09 & 15\end{array}$

$1.4 \quad 0.09$

0.14

$1.4 \quad 0.11$

0.03

0.21

6.20 .15

120

2.2

0.14
Mn

AI

Si

.

USW $\mathrm{H}-4$

$\begin{array}{lrrrrrrrrrr}628 & 8.7 & 8.0 & 0.35 & 114 & 4.1 & 0.26 & 0.05 & 0.09 & 0.04 & 11.3 \\ 683 & 8.6 & 7.3 & 0.21 & 107 & 3.5 & 0.34 & 0.12 & 0.10 & 0.04 & 26.4 \\ 721 & 8.6 & 8.3 & 0.23 & 109 & 3.4 & 0.40 & 0.20 & 0.08 & 0.06 & 26.5 \\ 792 & 8.4 & 12.4 & 0.25 & 105 & 3.2 & 0.38 & 0.86 & 0.13 & 0.05 & 26.3 \\ 869 & 9.6 & 3.9 & 0.14 & 99 & 3.8 & 0.33 & 0.01 & <0.01 & 0.06 & 26.4 \\ 908 & 8.6 & 12.8 & 0.25 & 92 & 3.5 & 0.27 & <0.05 & 0.08 & 0.08 & 25.9 \\ 1036 & 8.7 & 11.4 & 0.22 & 93 & 3.2 & 0.26 & 0.16 & 0.08 & 0.09 & 25.4 \\ 1187 & 8.6 & 7.7 & 0.16 & 98 & 3.3 & 0.21 & <0.05 & 0.09 & 0.06 & 26.0\end{array}$

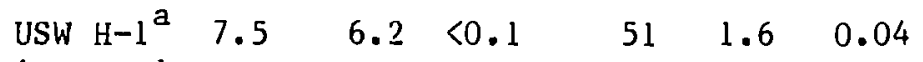

19

integral

$\begin{array}{lllllllllll}\text { USW H-4 } & 7.4 & 10.8 & 0.19 & 84 & 2.6 & 0.16 & 0.03 & 0.005 & 0.04 & 25.9\end{array}$ intergal

$a_{\text {Data from L. Benson et al. }}{ }^{1}$ 
TABLE VI

COMPOS ITION OF GROUNDWATE RS

FROM YUCCA MOUNTAIN WELLS

"THIEF" SAMPLES

\begin{tabular}{|c|c|c|c|c|c|c|c|c|c|}
\hline \multirow{2}{*}{$\begin{array}{l}\text { Well and } \\
\text { Depth } \\
(\mathrm{m}) \\
\end{array}$} & \multicolumn{7}{|c|}{$\begin{array}{c}\text { Concentration } \\
(\mathrm{mg} / \mathrm{l})\end{array}$} & \multirow[b]{2}{*}{$\mathrm{Eh}^{\mathrm{a}}$} & \multirow[b]{2}{*}{$\begin{array}{c}\text { Alkalinity } \\
(\text { meg/l) }\end{array}$} \\
\hline & $\mathrm{F}^{-}$ & $\mathrm{Cl}^{-}$ & $\mathrm{SO}_{4}^{2-}$ & $\mathrm{NO}_{2}^{-}$ & $\mathrm{NO}_{3}^{-}$ & $\mathrm{O}_{2}$ & $\mathrm{~s}^{2-}$ & & \\
\hline \multicolumn{10}{|l|}{ USW $\mathrm{H}-1$} \\
\hline 610 & 12.7 & 24.6 & 13.9 & N.D. & N.D. & 3.4 & N.D. & 270 & 3.49 \\
\hline 915 & 17.7 & 8.3 & 34.4 & $N \cdot D$. & N.D. & 1.3 & $6.4 \times 10^{-2}$ & -40 & 5.86 \\
\hline 1220 & 13.1 & 8.4 & 60.9 & N.D. & N.D. & 1.2 & $6.4 \times 10^{-5}$ & -25 & 5.90 \\
\hline 1800 & 16.8 & 9.5 & 50.0 & N.D. & N.D. & $<1.2$ & $3.2 \times 10^{-2}$ & -150 & 4.25 \\
\hline
\end{tabular}

USW $\mathrm{H}-4$

628

5.47

32.0

N.D. N.D. 0.1

$6.4 \times 10^{-1}$

$-160$

2.96

683

4.2

$7.8 \quad 24.4$

N.D. N.D. <0.1

32

$-158$

2.69

721

3.3

7.

N.D. 0.1

33

$-190$

2.75

792

3.0

$7.6 \quad 24.8$

N.D. N.D. <0.1

6

$-177$

2.70

869

4.4

$8.8 \quad 27.6<0.1$

$0.2<0.1$

6

$-191$

2.23

908

2.8

7.

N.D.

$1.3<0.1$

$6.4 \times 10^{-2}$

$-160$

2.46

1036

2 .

7.

N.D. $<0.5<0.1$

6

$-171$

2.53

1181

$2.7 \quad 7.0$

24.

N.D. $<0.5<0.1$

6

$-159$

2.42

USW $\mathrm{H}-1^{\mathrm{b}} \quad 1.0 \quad 5.8 \quad 19$

2.00

integral

USW $\mathrm{H}-4$

$\begin{array}{llll}4.5 & 6.2 & 23.9 \quad \text { N.D. }\end{array}$

$4.7 \quad 5.8$

N.D.

216

2.82

\begin{abstract}
integral
\end{abstract}

\footnotetext{
$a_{m V}$ vs $\mathrm{H}_{2}$ electrode.

$\mathrm{b}_{\text {Data from L. Benson, et al. }}{ }^{1}$
} 
(2) Pore water, in equilibrium with zeolitized Calico Hills tuff or Prow Pass tuff, will be quite similar in composition to the $\mathrm{NaHCO}_{3}$ waters found in the wells listed in Tables I through IV. The composition is a result of the reaction of volcanic glass and water to form the zeolitzed tuffs. 17,18 Infiltration water in contact with vitric Calico Hills tuff will approach this same composition.

\section{B. Saturated Zone}

An examination of water compositions listed in Tables I through IV shows that sodium is the principal cation and that carbonate (reported in terms of alkalinity) is the principal anion. For the observed range of $\mathrm{pH}$, carbonate exists primarily as $\mathrm{HCO}_{3}^{-}$in solution, so that all the waters sampled are principally sodium bicarbonate waters. Most of the waters are relatively dilute, in the range of 200 to $400 \mathrm{mg} / \ell$ total dissolved solids. However, water from the carbonate aquifer (UE-25p $\$ 1$ ) contains over $1000 \mathrm{mg} / \ell$ total dissolved solids and is the most concentrated water discussed in this report.

The molar distribution of anions in the water is relatively uniform for

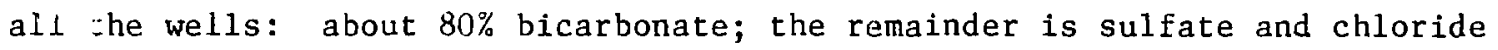
(usually present in nearly equal molar concentrations) and fluoride (in varying concentrations). ${ }^{1}$ The varjation of fluoride content among various wells will be discussed later. The: molar distribution of cations is somewhat more variable; sodium ranges from a high of over $95 \%$ to a low of abcut $65 \%$. Calcium, potassium, and magnesium are the other cations present in significant concentrations. We can gain some insight into the cation distribution from examining Figs. 3 and 4, which show ternary diagrams of relative sodiumpotassium-calcium content (Fig. 3) and relative sodium-potassium-magnesium content (Fig. 4) of the waters from Tables I to IV. Data from three other wells are also shown on these figures; Wells UE-19e and U-20a-2 are located on Pahute Mesa, ${ }^{19}$ and Well $\# 9$ is located in the Amargosa Desert ${ }^{20}$ (see Tables VII and VIII). These wells were included because groundwater at Yucca Yountain is probably derived by subsurface flow from recharge areas at higher iltitudes to the north, such as Pahute Mesa, $2 i$ and because the Amargosa besert is considered a discharge area for water from Yucca Mountain. 17, 21 lhe shaded areas in Figs. 3 and 4 represent the range of compositions of interstitial and fracture waters, as observed by White et al. ${ }^{17}$ at Rainier Mesa. Rainier Mesa is also north of Yucca Mountain and may be part of the 


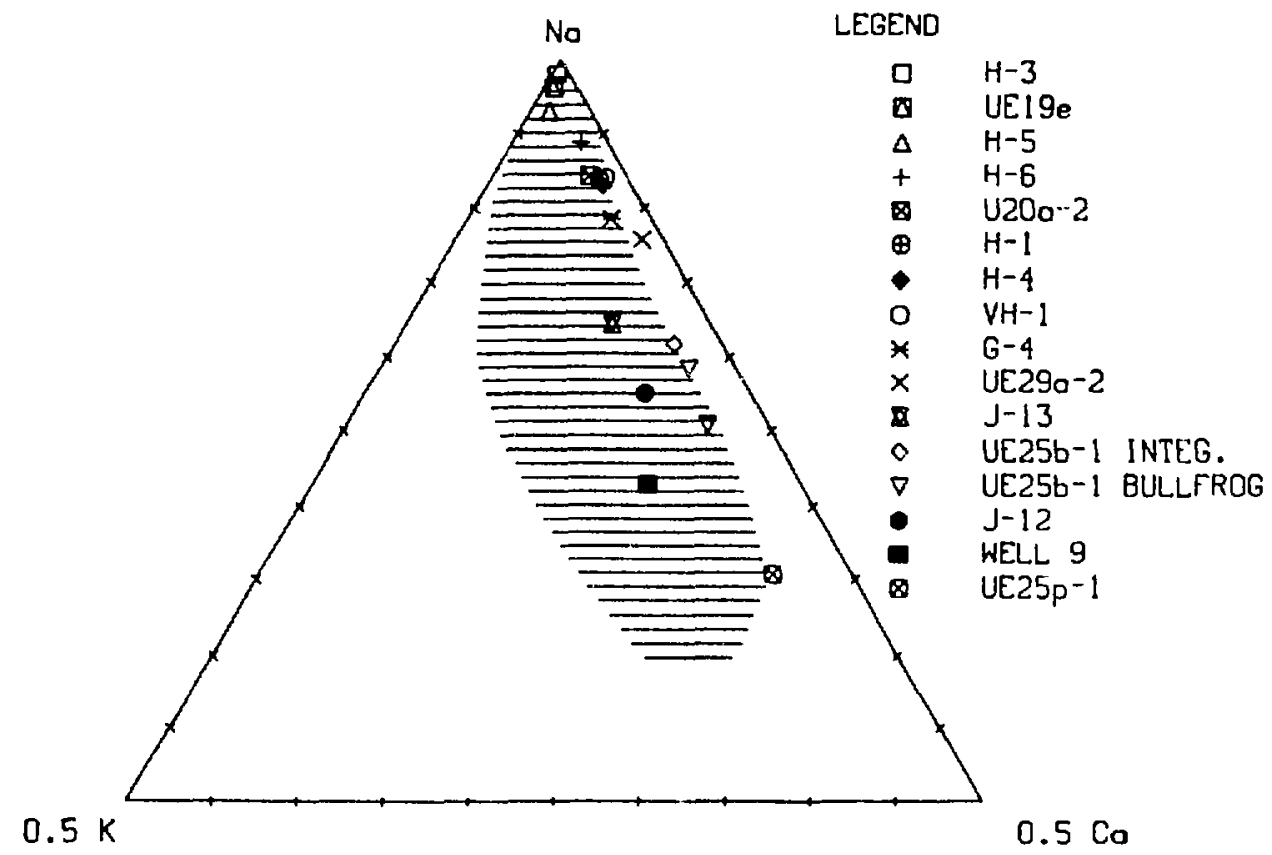

Fig. 3. Relative Na-K-Ca concentration in Yucca Mountain water.

recharge area. Wells on Yucca Mountain and just to the west (USW H-j, H-'), and $H-6)$ plot nearest the sodium apex of Fig. 3 . Wells on ilu ait. and washes (USW $\mathrm{H}-1, \mathrm{H}-4, \mathrm{G}-4$, and $J-13$ and $U E-25 \mathrm{~b}$ it 1 ) show increasing level.. of calcium. The carbonate aquifer well (UE-25pli ) in weli from the Amargosa Desert (Wel1 $\$ 9$ ) show the highest relative calcium contents. The two wells on Pahute Mesa (UE-19e and U-20a-2) are simflar to the wells on and just east of Yucca Mountain (see Fig. 3); this is consistent with a relation in actual recharge or recharge mechanisms between the two areas. All the wells plot in a band that is generally parallel to the sodium-calcium axis in Fig. 3, which indicates that the relative potassium content is nearly constant. The trends seen in Fig. 4 are sinilar to those in Fig. 3; however, 


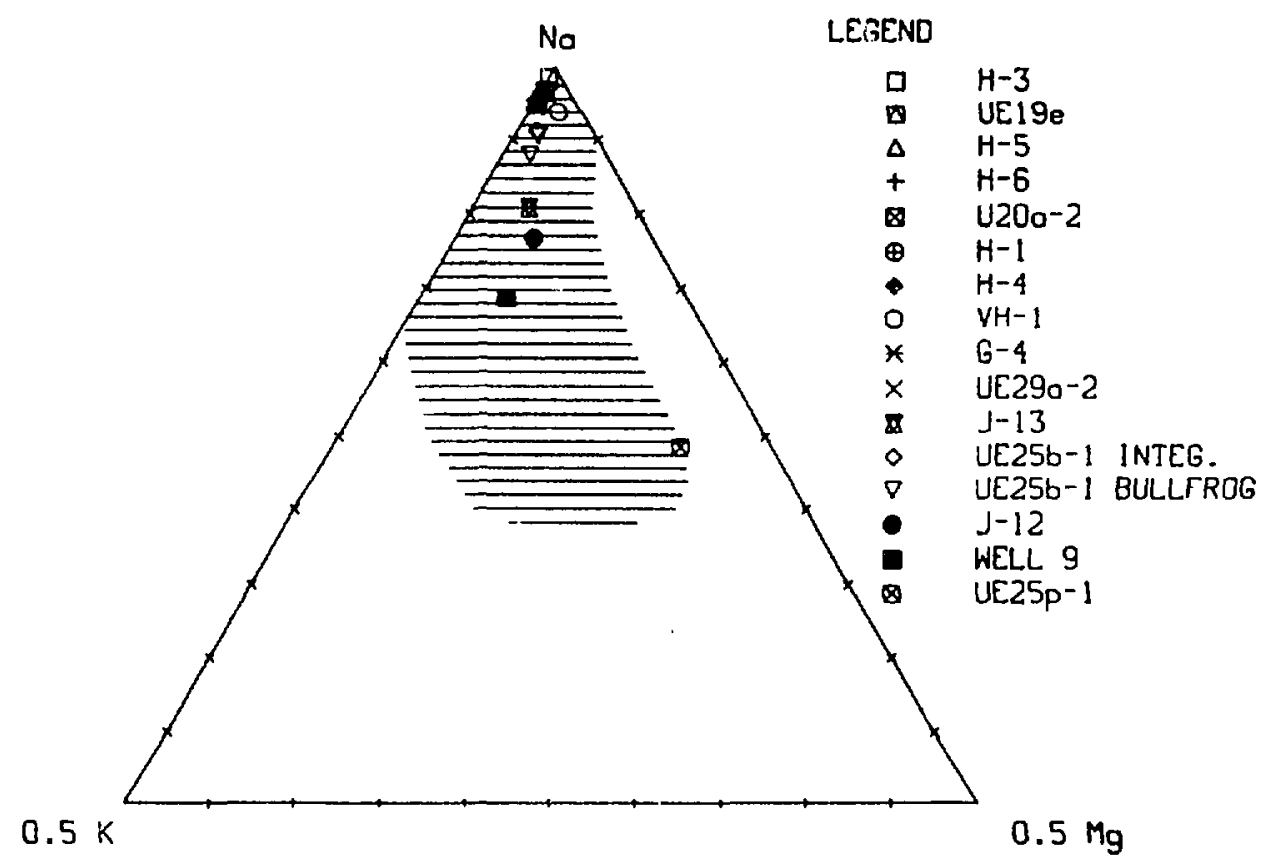

Fig. 4. Relative Na-K-Mg concentration in Yucca Mountain water.

many of the wells are bunched near the sodium apex in Fig. 4 because of the low magnesium content of their water.

The reaction of groundwater with volcanic glass in the tuff near Yucca Mountain and at the NTS has been proposed as the primary mechanism for formation of the mineral assemblage that is currently observed. 22 In one particular location, Rainier Mesa in the north-central section of NTS, studies of groundwater chemistry, mineral assemblage, and volcanic-glass dissolution rates have produced a specific model for the area. ${ }^{17,23}$ In the model, water saturated with $\mathrm{CO}_{2}$ reacts with volcanic glass. The various species composing the glass are leached or dissolved from the glass at different rates. Groundwater chemistry is related to the relative dissolution rates of species from the glass and the identity of minerals that precipitate during the dissolution process. To calculate the sodium, 
TABLE VII

ELEMENTAL CCNCENTRATION IN GROUNDWATER FROM PAHU'CE MESA WELLS AND A WELL IN THE AMARGOSA DESERT

\begin{tabular}{|c|c|c|c|c|c|c|c|c|c|c|}
\hline \multirow[b]{2}{*}{ Well } & \multirow[b]{2}{*}{$\mathrm{pH}$} & \multicolumn{9}{|c|}{$\begin{array}{c}\text { Concentration } \\
(\mathrm{mg} / \mathrm{l})\end{array}$} \\
\hline & & $\overline{\mathrm{Ca}}$ & $\mathrm{Mg}$ & $\mathrm{Na}$ & $\mathrm{K}$ & $\overline{\mathrm{Li}}$ & $\mathrm{Fe}$ & $\mathrm{Mn}$ & $\bar{A}$ & $\widehat{S i}$ \\
\hline UE $-19 e$ & 7.7 & 0.4 & 0.1 & 38 & 0.9 & 0.04 & $<0.01$ & 0.07 & $<0.01$ & 30 \\
\hline $\mathrm{U}-20 \mathrm{a}-2$ & 7.9 & 5.9 & 0.2 & 55 & 2.2 & 0.05 & $<0.01$ & $<0.01$ & 0.02 & 21 \\
\hline \multirow[t]{3}{*}{$\# 9$} & 8.1 & 20.0 & 2.7 & 42 & 9.0 & & & & & 13 \\
\hline & \multicolumn{6}{|c|}{$\begin{array}{l}\text { Concentration } \\
(\mathrm{mg} / \mathrm{l})\end{array}$} & & & & \\
\hline & F- & $\mathrm{Cl}^{-}$ & & & $\mathrm{NO}_{3}^{-}$ & $\mathrm{HCO}_{3}^{-}$ & & & & \\
\hline $\mathrm{UE}-19 \mathrm{e}$ & 0.7 & 4.6 & & .0 & 2.8 & 81 & & & & \\
\hline$U-20 a-2$ & 2.8 & 10 & 2 & & 0.7 & 110 & & & & \\
\hline$\# 9$ & & 7.5 & & & & & & & & \\
\hline
\end{tabular}

TABLE VIII

ELEMENTAL CONCENTRATION IN GROUNDWATER FROM PAHUTE MESA WELLS AND A WELL IN THE AMARGOSA DESERT

Concentration

(mmols/l)

\begin{tabular}{|c|c|c|c|c|c|c|c|c|c|}
\hline \multirow[b]{2}{*}{ We11 } & \\
\hline & $\mathrm{Ca}$ & $\overline{\mathrm{Mg}}$ & $\overline{\mathrm{Na}}$ & $\mathrm{K}$ & $\mathrm{Li}$ & $\mathrm{Fe}$ & $\mathrm{M} n$ & A1 & $\mathrm{Si}$ \\
\hline$U E-19 e$ & 0.01 & 0.0041 & 1.65 & 0.023 & 0.006 & $<0.0002$ & 0.001 & $<0.0004$ & 1 \\
\hline$U-20 a-2$ & 0.15 & 0.0082 & 2.39 & 0.056 & 0.007 & $<0.0002$ & $<0.0002$ & 0.0008 & 0.73 \\
\hline$\$ 9$ & 0.50 & 0.11 & 1.83 & 0.23 & & & & & 0.46 \\
\hline
\end{tabular}

\begin{tabular}{|c|c|c|c|c|c|}
\hline & & $\begin{array}{r}\text { Conce } \\
\quad(r \\
\end{array}$ & $\begin{array}{l}\text { ratior } \\
\text { lse) }\end{array}$ & & \\
\hline & $\underline{F-}$ & $\mathrm{Cl}^{-}$ & $\mathrm{SO}_{4}^{2-}$ & $\mathrm{NO}_{3}^{-}$ & $\begin{array}{c}\text { Alkalinity } \\
\text { (meg/l) }\end{array}$ \\
\hline$U E-19 e$ & 0.04 & 0.13 & 0.08 & 0.04 & \\
\hline $\mathrm{U}-20 \mathrm{a}-2$ & 0.15 & 0.28 & 0.29 & 0.01 & \\
\hline$\# 9$ & & 0.21 & 0.29 & & 2.43 \\
\hline
\end{tabular}


potassium, calcium, and magnesium composition of the groundwater and to compare it with observed compositions, Claassen and white 23 performed a material-balance calculation using their measured dissolution rates and by assuming precipitation of a montmorillonite clay with a specific composition. Kerrisk ${ }^{18}$ has described reaction-path calculations of groundwater chemistry and inineral formation based on this model.

Mineralogy of this area has been studied at Rainier Mesa, ${ }^{17}$ Yucca Mountain, 24,25 Pahute Mesa, 26 and the NTS in general, 22 and a sequence of stages in mineral evolution has been defined. The initial stage of original volcanic glass is followed by a cristobalite, smectite clay, and zeolite (clinoptilolite and mordenite) mixture. Interstitial water compositiona at Rainier Mesa are generally associated with progress from the initial volcanic glass to this mixture. 17,23 The third stage in mineral evolution is a quartz, analcime, and illite mixture; the fourth and final product is a quartz, albite, and potassium-feldspar mixture, with calcite possibly present. These stages obviously represent an idealization of the continuous changes that occur; however, such a delineation is useful because there are large areas at XrS where minerals from the various stages predominate.

There are two questions of interest concerning the observed water compositions and the models relating water chemistry and mineralogy at Yucca Mountain.

(1) Are the observed water compositions consistant with the models?

(2) Can the water compositions be bounded well enough to estimate radionuclide transport?

The similarity of the relative cation and anion compositions of water from the tuffaceous aquifers at Yucca Mountain, Pahute Mesa, and Rainier Mesa indicates a hydrologic connection or a similarity in reaction mechanism during recharge. Thus, data from Wells USW H-3, H-5, and $H-6$ are near data from Well Uf -19 e on Figs. 3 and 4 , and data from Wells USW H-1, H-4, and VH-1 are near data from Weil $\mathrm{U}-20 \mathrm{a}-2$ on these figures. The relative anion compositions of these waters are also quite similar. These compositions are consistant with the proposed models of vitric tuff dissolution and precipitation of silica, clay, and zeolite minerals. $17,18,23$ water compositions with increasing relative calcium and magnesium contents (moving toward the 
calcium or magnesium apex on Figs. 3 and 4) could be the result of

(1) recharge through valley fill that contains carbonate deposits or

(2) mixing of waters from the tuffaceous and carbonate aquifers. 20 Thus, the mineralogy and water compositions appear consistant.

A major difference between some of the waters in Tables $I$ to IV is that the oxidation-reduction potential ( $\mathrm{Eh}$ ) of the water from Well USW $\mathrm{H}-3$ and the packed off Bullfrog zone of Well UE-25b非 1 are reducing: $-143 \mathrm{mV}$ vs hydrogen electrode in the case of Well USW H-3. This characteristic of the water beneath Yucca Mountain could be extremely important. The solubilities of many waste elements such as uranium, plutonium, neptunium, and technetium are greatly affected by the oxidation-riduction potential of the water. The water in Well USW $\mathrm{H}-3$ is sufficiencly reducing to reduce all the above elements to their most insoluble oxidation state. There are no models describing water Eh at Yucca Mountain. However, measured values of Eh from these two wells are more representative of water Eh at depth because isolated zones at depth were pumped and anaerobic sampling techniques were employed.

The range of compositions in water observed near Yucca Mountalin and along possible flow paths can be bounded by the data presented in Tables I to IV, Figs. 3 and 4 , and the information presented by Benson et al. ${ }^{1}$ Further drilling and testing along flow paths to the accessible environment would probably not enlarge these ranges significantly. How ver, the sensitivity of radionuclide transport to these composition ranges has not yet been determined. If performance assessment calculations indicate that the uncertainty in radionuclide-transport results, which is related to the possible range of water compositions, is too large, further experimental work may be necessary to narrow these ranges. One aspect of this sensitivity, the effect of water composition on waste-element solubilities, is discussed later.

C. "Thief" Samples

Two wells were sampled using "thief" sampling bottles; Well USW $\mathrm{H}-1$ approximately 1 year after the well was pumped and the pump removed, and Well USW H-4 within a week after it was pumped and the pump was removed. Results ${ }^{7,10}$ from these two experiments were presented in Tables $V$ and VI. The composition of the integral water samples from these two wells are also presented for comparison. 
It is not clear what the results show. After a year of the well being stagnant and only internal heads directing the flow of water, one would expect that the compositions at each depth in Well USW H-1 would be different and would be in equilibrium with the tuff at that point. Indeed each of the samples from Well USW $\mathrm{H}-1$ is different from the others and also differs from the integral samples. The $\mathrm{F}^{-}, \mathrm{Cl}^{-}, \mathrm{SO}_{4}^{2-}, \mathrm{HCO}_{3}^{-}, \mathrm{s}^{2-}$, and $\mathrm{Na}^{+}$are all generally much higher in the "thief" samples; the Eh is negative, and silicon is lower. Interestingly, with the exception of the presence of sulfide, the three deep "thief" samples from Well USW $\mathrm{H}-1$ resemble the water from Well USW H-3 (see Tables I to IV) more than the integral sample from Well USW $\mathrm{H}-1$. The Well USW H-3 water was pumped entirely from the Tram unit, which is about $1000 \mathrm{~m}$ deep at Well USW $\mathrm{H}-1$.

The "thief" sample compositions of Well USW H-4, however, are surprisingly consistent and similar to those of the integral sample except for sodium, $\mathrm{pH}$, and redox-related species (sulfide, $\mathrm{O}_{2}$, and $\mathrm{NO}_{3}^{-}$). They exhibit very little variation with depth. Perhaps the well had not been pumped enough and remnants of Well J-13 drilling water are still being observed or perhaps removal of the pump mixed the contents of the well and 1 week was too short a time for the waters at the permeable zones to equilibrate. Like the Well USW H-1 "thief" samples, those from Well USW H-4 indicate that the water is reducing (negative Eh, sulfide present, and no dissolved oxygen). The integral sample from Well USW H-4 was oxidizing.

The data cannot be interpreted at this time. A series of "thief" samples from a well that has been pumped until formation water is obtained must be taken and studied as a function of time of equilibration before interpretation can be assured. The reducing conditions observed with the "thief" samples and the data from Wells USW H-3 and UE-25b\#1 are further indications that formation water at depth may be reducing.

\section{Speciation and Solubility}

For purposes of estimating concentrations of waste elements along the flow paths fiom a Yucca Mountain repository to the accessible environment, the speciation and solubility of waste elements in three specific water compositions can be used. 
(1) The composition of Well USW $\mathrm{H}-3$ is indicative of water below the proposed repository site.

(2) Water from Well UE-25p非 1 reprasents the carbonate aquifer underlying much of the area and is the most concentrated groundwater possible along the flow path.

(3) We11 J-13 water is typical of wells surrounding Yucca Mountain; this well is capable of producing large volumes of water from a permeable zone at or near the static water level. The composition of such waters may be influenced greatly by juvenile recharge water.

The solubilities of six waste elements (uranium, plutonium, americium, strontiur, radium, and technetium) in waters from three wells in the vicinity of Yucca Mountain have been calculated with the EQ3 chemical equilibrium computer program and the current thermodynamic data base. For these calculations, the compositions of the waters from Wells J-13, the paleozoic aquifer of UE-25p\#1, and USW H-3 were taken from Tables I and II. Thege three compositions are also being used for sorption measurements at Los Alamos.

Table IX lists the solubility, the identity of the solid controlling solubility, and the primary aqueous species for the six waste elaments in the three waters. The features of the water most affecting these quantities are the $\mathrm{pH}$ and $\mathrm{Eh}$ of the water and the avallability of aqueous species that complex with the waste element. In addition to hydroxyl, carbonate, sulfate, and fluoride are the most important complexing anions.

Uranium is primarily in the VI oxidation state in water from Wells $\mathrm{J}-13$ and UE-25p非1. The difference in the solid that controls solubility in Well UE-25p\# 1 and in We11 J-13 is caused by the increased carbonate content of We11 UE-25p非 1 water. The low Eh of water from We11 H-3 results in both IV and VI oxidation states and a much lower solubility than in water from the other wells.

Plutonium is primarily in the $V$ and VI oxidation states in water from We11 J-13; in water from the other two wells, it is primarily in the IV oxidation state. The hydrous plutonium oxide used to control plutonium solubility results in higher solubilities than would be calculated with crystalline plutonium oxide. However, crystalline plutonfum oxide may never 
TABLE IX

WASTE-ELEMENT SOLUBILITIES IN WATER FROM THREE YUCCA MOUNTAIN WELLS

\begin{tabular}{|c|c|c|c|c|c|c|}
\hline \multirow{2}{*}{$\begin{array}{l}\text { Uranlum } \\
\text { Solubllity }(m / \ell)\end{array}$} & \multicolumn{2}{|l|}{ We11 J-13 } & \multicolumn{2}{|c|}{ (1298 to $1792 \mathrm{~m})$} & \multicolumn{2}{|c|}{ Well USW H-3 } \\
\hline & $3.65 \times 10^{-3}$ & & $1.74 \times 10^{-3}$ & & $4.05 \times 10^{-8}$ & \\
\hline Soltd & Schoepite $^{a}$ & & Rutherfordine ${ }^{b}$ & & Uraninite $^{c}$ & \\
\hline Primary aqueous specles & $\left(\mathrm{UO}_{2}\right)_{2} \mathrm{CO}_{3}(\mathrm{OH})_{3}^{-}$ & $(98 \%)$ & $\mathrm{UO}_{2}\left(\mathrm{CO}_{3}\right)_{2}^{2-}$ & $(54 \%)$ & $\mathrm{UO}_{2}\left(\mathrm{CO}_{3}\right)_{3}^{4-}$ & $(86 z)$ \\
\hline & $\mathrm{UO}_{2}\left(\mathrm{CO}_{3}\right)_{2}^{2-}$ & (1\%) & $\left(\mathrm{UO}_{2}\right)_{2} \mathrm{CO}_{3}(\mathrm{OH})_{3}^{-}$ & $(31 \%)$ & $\mathrm{U}(\mathrm{OH})_{5}^{-}$ & (8\%) \\
\hline & $\mathrm{Uo}_{2}\left(\mathrm{Co}_{3}\right)_{3}^{4-}$ & $(137)$ & $\mathrm{UO}_{2}\left(\mathrm{CO}_{3}\right)_{2}^{2-}$ & $(7 \%)$ & & \\
\hline & $\mathrm{UO}_{2} \mathrm{CO}_{3}^{\circ}$ & $(2 \%)$ & & & & \\
\hline $\begin{array}{l}\text { Plutonfum } \\
\text { Solubility }(\mathrm{m} / \ell)\end{array}$ & $1.79 \times 10^{-6}$ & & $3.11 \times 10^{-8}$ & & $1.33 \times 10^{-5}$ & \\
\hline Soltd & $\mathrm{Pu}(\mathrm{OH})_{4}^{\mathrm{d}}$ & & $\mathrm{Pu}(\mathrm{OH})_{4}^{\mathrm{d}}$ & & $\mathrm{Pu}(\mathrm{OH})_{4}^{\mathrm{d}}$ & \\
\hline Primary aqueous species & $\mathrm{PuO}_{2}^{+}$ & $(717)$ & $\mathrm{Pu}(\mathrm{OH})_{5}^{-}$ & $(94 \%)$ & $\mathrm{Pu}(\mathrm{OH})_{5}^{-}$ & $(100 \%)$ \\
\hline & $\mathrm{PuO}_{2} \mathrm{~F}_{3}^{-}$ & $(20 \%)$ & $\mathrm{Pu}(\mathrm{OH})_{4}^{\circ}$ & $(6 z)$ & & \\
\hline & $\mathrm{Pu}(\mathrm{OH})_{5}^{-}$ & $(3 \%)$ & & & & \\
\hline & $\mathrm{PuO}_{2}\left(\mathrm{CO}_{3}\right)_{2}^{2-}$ & (2z) & & & & \\
\hline & $\mathrm{PuO}_{2} \mathrm{~F}_{4}^{2-}$ & $(2 \%)$ & & & & \\
\hline $\begin{array}{l}\text { Americlum } \\
\text { Solubility }(\mathrm{m} / \ell)\end{array}$ & $9.87 \times 10^{-9}$ & & $2.16 \times 10^{-8}$ & & $6.85 \times 10^{-10}$ & \\
\hline Solid & $\mathrm{Am}(\mathrm{OH}) \mathrm{CO}_{3}$ & & $\mathrm{Am}(\mathrm{OH}) \mathrm{CO}_{3}{ }^{\mathrm{e}}$ & & $\mathrm{Am}(\mathrm{OH}) \mathrm{CO}_{3}$ & \\
\hline Primary aqueous spectes & $\mathrm{AmCO}_{3}^{+}$ & $(80 \%)$ & $\mathrm{AnCO}_{3}^{+}$ & $(83 \%)$ & $\mathrm{Am}\left(\mathrm{CO}_{3}\right)_{2}^{-}$ & (46\%) \\
\hline & $\mathrm{AnOH}^{2+}$ & (8\%) & $\mathrm{Am}\left(\mathrm{CO}_{3}\right)_{2}^{-}$ & $(6 \%)$ & $\operatorname{Am}(\mathrm{OH})_{3}^{\circ}$ & $(36 \%)$ \\
\hline & $\operatorname{Am} F^{2+}$ & $(4 \%)$ & $\mathrm{AmF}^{2+}$ & $(4 \%)$ & $\operatorname{Am}(\mathrm{OH})_{2}^{+}$ & (12\%) \\
\hline & $\mathrm{Am}^{3+}$ & $(3 \%)$ & $\mathrm{AmSO}_{4}^{+}$ & $(2 \%)$ & $\mathrm{AmCO}_{3}^{+}$ & (5\%) \\
\hline & $\mathrm{Am}\left(\mathrm{CO}_{3}\right)_{2}^{-}$ & $(3 \%)$ & $\mathrm{AmOH}^{2+}$ & $(2 \%)$ & & \\
\hline & & & $\mathrm{Am}^{3+}$ & $(2 \%)$ & & \\
\hline
\end{tabular}


TABLE IX (cont)

Strontium

Solubility $(\mathrm{m} / \ell)$

Sol1d

Primary aqueous spectes

Rad1um

Solub1lity $(\mathrm{m} / \ell)$

Solid

Primary aqueous spectes

Technetium

Solubility $(\mathrm{m} / \ell)$

Sol1d

Primary aqueous species

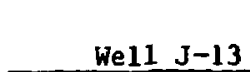

$$
8.04 \times 10^{-4}
$$

Strontiante ${ }^{f}$

$\mathrm{ST}^{2+}$

$\mathrm{SrSO}_{4}^{\circ}$

$3.39 \times 10^{-7}$
$\operatorname{RaSO}_{4}$
$\mathrm{Ra}^{2+}$

$\mathrm{Ra}^{2+}$

(99\%)

(96\%)

(4\%)

Large $e^{g}$

Large $e^{g}$

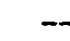

$\mathrm{TcO}_{4}^{-}$
We11 UE $-25 p * 1$
$(1298$ to $1792 \mathrm{~m})$

$5.27 \times 10^{-4}$

Strontianite $f^{f}$

$\mathrm{Sr}^{2+}$

$\mathrm{SrSO}_{4}^{\circ}$

$9.29 \times 10^{-8}$

$\mathrm{RaSO}_{4}$

$\mathrm{Ra}^{2+}$

(99\%)

(86\%)

(14\%)
(947)

(6\%)

$3.28 \times 10^{-6}$

Strontianite $\mathrm{f}^{\mathrm{f}}$

$S r^{2+}$

$\mathrm{SrSO}_{4}^{\circ}$

$2.94 \times 10^{-7}$

$\mathrm{RaSO}_{4}$

$\mathrm{Ra}^{2+}$

(99\%)

$2.06 \times 10^{-12}$

$\mathrm{Tc}_{3} \mathrm{O}_{4}$

$\mathrm{TcO}_{4}^{-}$

$\mathrm{TcO}(\mathrm{OH})_{2}$

a Schoepte is $\mathrm{UO}_{2}(\mathrm{OH})_{2} \cdot \mathrm{H}_{2} \mathrm{O}$.

butherfordine is $\mathrm{UO}_{2} \mathrm{CO}_{3}$.

Uraninite is $\mathrm{UO}_{2}$.

dAlso known as hydrous $\mathrm{PuO}_{2}$; crystalline $\mathrm{PuO}_{2}$ would give a much lower solubility but may not control solubility.

${ }^{\mathrm{A}} \mathrm{m}_{2}\left(\mathrm{CO}_{3}\right)_{3}$ is less soluble under these conditions, but the thermodynamic data for this solid are uncertain.

f Strontianite is $\mathrm{SrCO}_{3}$.

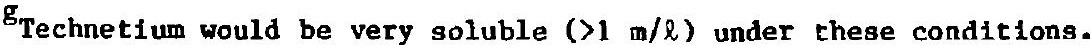


precipitate from solution, and thus, may not exist as a control on solubility. The solubility in water from Well USW $\mathrm{H}-3$ is higher than that from Well UE-25p\#1 because Wel1 USW $H-3$ water has a higher $p H$, which results in more complex formation with hydroxyl.

In natural waters, americtum is only in the III oxidation state. The solubility is controlled mainly by the availability of complexing anions (including hydroxyl) and anions that participate in the solid-forming reactions.

Both strontium and radium are particularly simple; they exist in only one oxidation state and form few complexes. Their solubilities are controlled by the availability of anions that participate in the solidforming reactions.

The solubility of technetium is controlled primarily by the redox conditions of the water. Under oxidizing conditions (for example, in Wells $\mathrm{J}-13$ and UE-25p非), technetium is very soluble. The Eh of water from We11 UE-25p\#1 was not measured "on 1ine" during a long pumping cycle. Therefore, air from the drilling process may still be in the water. Reduced irontitanium oxides are observed in the mineralogy at $1140 \mathrm{~m}$, so one might expect the water to have a lower Eh. Below an $\mathrm{Eh}$ of about $0 \mathrm{mV}$, lower oxidation states of technetium become important. In Well USW H-3 water, technetium is only slightly soluble.

\section{E. pH Buffering Capacity}

The water compositions found at Yucca Mountain are at or near equilibrium with the local minerals and would be unlikely to change significantly if conditions remain stable. However, if conditions change, it is of interest to understand the capacity of the water and mineral system to accommodate these changes. One aspect of this general problem, the system's response to addition of $\mathrm{H}^{+}$or $\mathrm{OH}^{-}$(that is, the $\mathrm{pH}$ buffering capacity) is discussed here.

Pure water, with no dissolved species, can undergo large changes in $\mathrm{pH}$ after small additions of strong acids or bases. However, when dissolved aqueous species are present, there are several types of chemical reactions that can reduce the $\mathrm{pH}$ change for a given addition of acid or base. Aqueous species that can buffer pH changes include weak acids and bases or metal ions that undergo hydrolysis. In water from Yucca Mountain, the aqueous species 
that have significant buffering capacity are carbonate, aqueous silica, and sulfate. The reactions involved are

$$
\begin{aligned}
\mathrm{H}_{2} \mathrm{CO}_{3} & =\mathrm{H}^{+}+\mathrm{HCO}_{3}^{-} & \operatorname{logK} & =-6.3, \\
\mathrm{HCO}_{3}^{-} & =\mathrm{H}^{+}+\mathrm{CO}_{3}^{2-} & \log \mathrm{K} & =-10.3, \\
\mathrm{H}_{4} \mathrm{SiO}_{4} & =\mathrm{H}^{+}+\mathrm{H}_{3} \mathrm{SiO}_{4}^{-} & \operatorname{logK} & =-9.7, \text { and } \\
\mathrm{HSO}_{4}^{-} & =\mathrm{H}^{+}+\mathrm{SO}_{4}^{2-} & \log \mathrm{K} & =-2.0 .
\end{aligned}
$$

Total carbonate is present in water from Yucca Mountain in the range of 2 to $4 \mathrm{mmols} / \ell$ in water 1 om the tuffaceous aquifer and up to $16 \mathrm{mmols} / \ell$ in water from the carbonate aquifer. Aqueous silica is normally present in the range of 0.5 to $1 \mathrm{mmol} / \ell$. Sulfate is present in the range of 0.1 to $0.4 \mathrm{mmols} / \ell$ in water from the tuffaceous aquifer and up to $1 \mathrm{mmol} / \ell$ in water from the carbonate aquifer. Carbonate and aqueous silica would exhibit their primary buffering capacity in the pH range of 6 to 10 . Sulfate would only be an effective buffer at a $\mathrm{pH}$ near 2 .

Solids that are in equilibrium with an aqueous solution or that can precipitate from it can also affect the buffering capacity of the water. Reactions involving the clays, zeolites, and feldspars that are found at Yucca Mountain generally include the production or consumption of $\mathrm{H}^{+}$. Prectpitation or dissolution of calcite or dolomite can also affect water $\mathrm{pH}$. The minerals in contact with water at Yucca Mountain exhibit some pH control over the water ${ }^{18}$ and will contribute to the buffering capacity of the water/mineral system. There are a large number of possible reactions among the minerals present. Thus, the specific reactions involved and the $\mathrm{pH}$ range over which they are effective would be difficult to define without detailed chemical-equilibrium calculations. These calculations are discussed below. A series of calculations of the effects of adding $\mathrm{H}^{+}$or $\mathrm{OH}^{-}$to Yucca Mountain water has been done using the EQ3/6 chemlcal-equilibrium computer programs. ${ }^{27}$ Water from Well J-13 was used as characteristic of Yucca Mountain water (see Tables I through IV). The calculations employed the reaction-path capabilities of EQ6 to simulate the addition of $\mathrm{H}^{+}, \mathrm{OH}^{-}$, or other reactants that could affect the pH of the water, to Well $\mathrm{J}-13$ water 
alone and to We11 J-13 water with specific minerals present. For the calculations, it was assumed that quartz and chalcedony would not precipitate; under these conditions, cristobalite is the stable silica phase. This procedure keeps the aqueous silica activity within the range observed in water from Yucca Mountain. When watcr of Well J-13 composition is used to start these calculations, a small amount of solid material precipitates before any additions are made. The solids, cristobalite, clinoptilolite, and nontronite, 18 were left in contact with the water for all calculations.

Figures 5 and 6 show the effect on $\mathrm{pH}$ of adding $\mathrm{H}^{+}$(as $\mathrm{HCl}$ ) and $\mathrm{OH}^{-}$(as $\mathrm{NaOH}$ ) to $1 \&$ of Well $\mathrm{J}-13$ water at $25^{\circ} \mathrm{C}$ without other minerals present. The initial $\mathrm{pH}$ was 7 . The dashed line in each figure represents the $\mathrm{pH}$ of pure water for the same conditions. For the addition of acid (Fig. 5), the buffering effects of $\mathrm{H}_{2} \mathrm{CO}_{3} / \mathrm{HCO}_{3}^{-}$in the $\mathrm{pH}$ range of 5.5 to 7 and $\mathrm{HSO}_{4}^{-} / \mathrm{SO}_{4}^{2-}$ near a $\mathrm{pH}$ of 3 are evident. For the addition of base (Fig. 6), the buffering effects of $\mathrm{HCO}_{3}^{-} / \mathrm{CO}_{3}^{2-}$ and $\mathrm{H}_{4} \mathrm{SiO}_{4} / \mathrm{H}_{3} \mathrm{SiO}_{4}^{-} j$. the $\mathrm{pH}$ range of 7 to 11.5 merge together. It is evident that Well J-13 water alone can accommodate about 2 mmols/ $\ell$ of acid or base without large changes in pH (see Figs. 5 and 6 ). This is a substantial fraction of the total anion or cation content of Well $\mathrm{J}-13$ water, which is about $3 \mathrm{meq} / \ell$.

To this point, the buffering capacity of water from Yucca Mountain has been discussed without reference to specific processes that could cause the $\mathrm{pH}$ changes. These processes san also add or remove other spectes from the water. One of the most 11 kely processes that could affect water $\mathrm{pH}$ is the oxidation of iron pyrite $\left(\mathrm{FeS}_{2}\right)$, which is responsible for actd waters assoclated with many mines. ${ }^{28}$ Reaction-path calculations were done in which pyrite was added to Well J-13 water with high Eh to simulate the avallability of dissolved oxygen to oxidtze the Iron and sulfide. No other minerals were assumed to be present. Figure 7 shows a plot of $\mathrm{pH}$ as a function of moles of pyrite oxidized in $1 \ell$ of water at $25^{\circ} \mathrm{C}$. This curve is essentially identical to the Well J-13 water curve in Fig. 5 (where $\mathrm{HCl}$ was added) if 1 mole of pyrite oxidized is equivilant to 4 moles of $\mathrm{H}^{+}$added. Most of the oxidized iron precipitates as hematite $\left(\mathrm{Fe}_{2} \mathrm{O}_{3}\right)$; the small amount of clinoptilolite originally present in equilibrium with the water is converted to nontronite, 


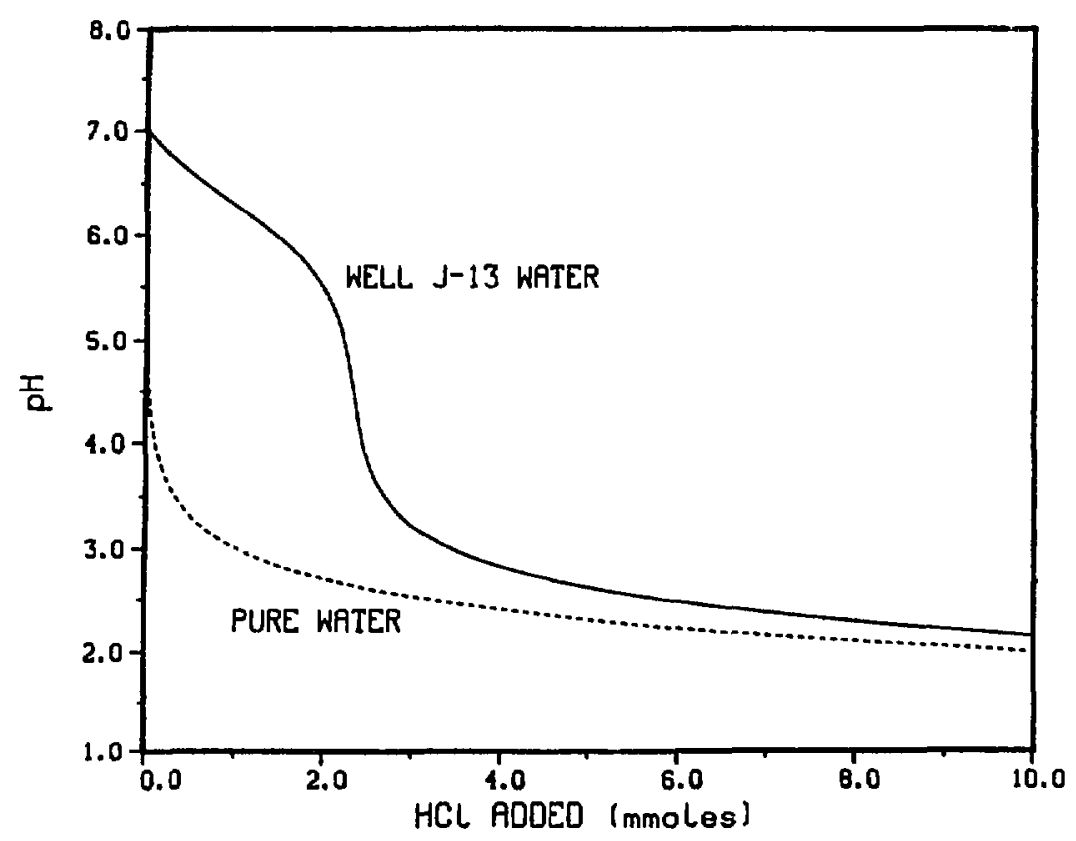

Fig. 5. The pH of Well J-13 water and pure water as a function of added HCl.

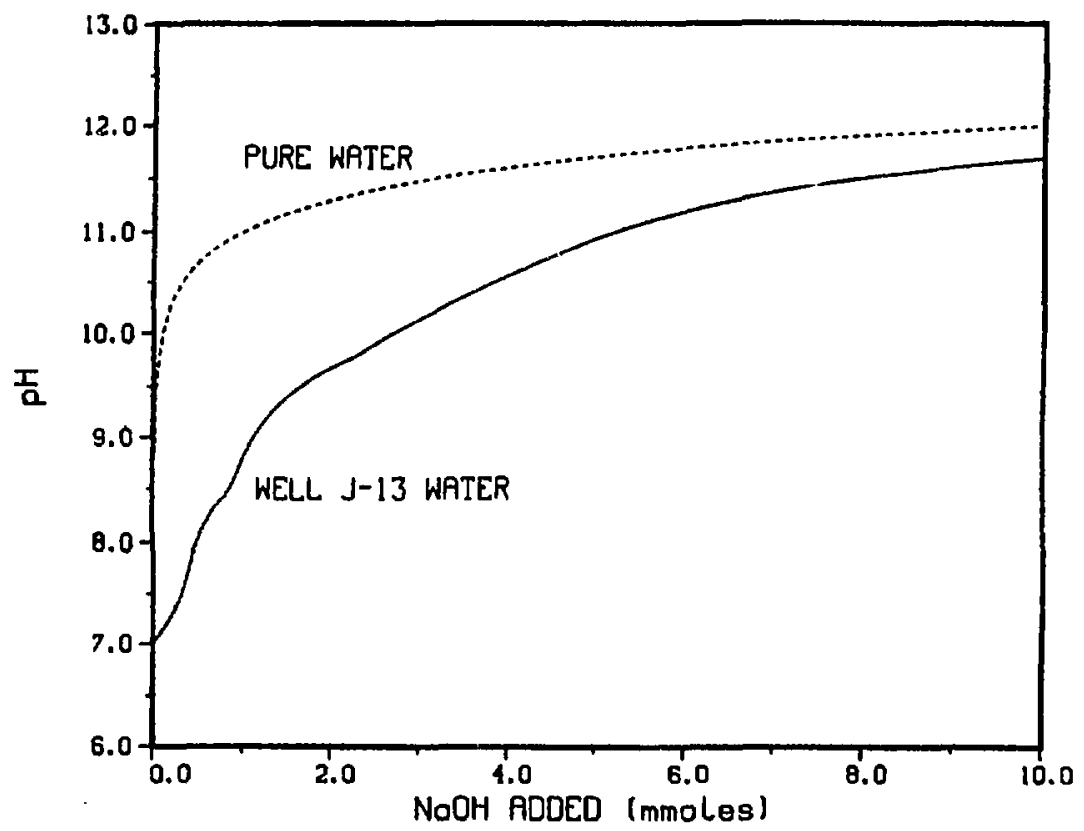

Fig. 6. The pH of Well J-13 water and pure water as a function of added NaOH. 


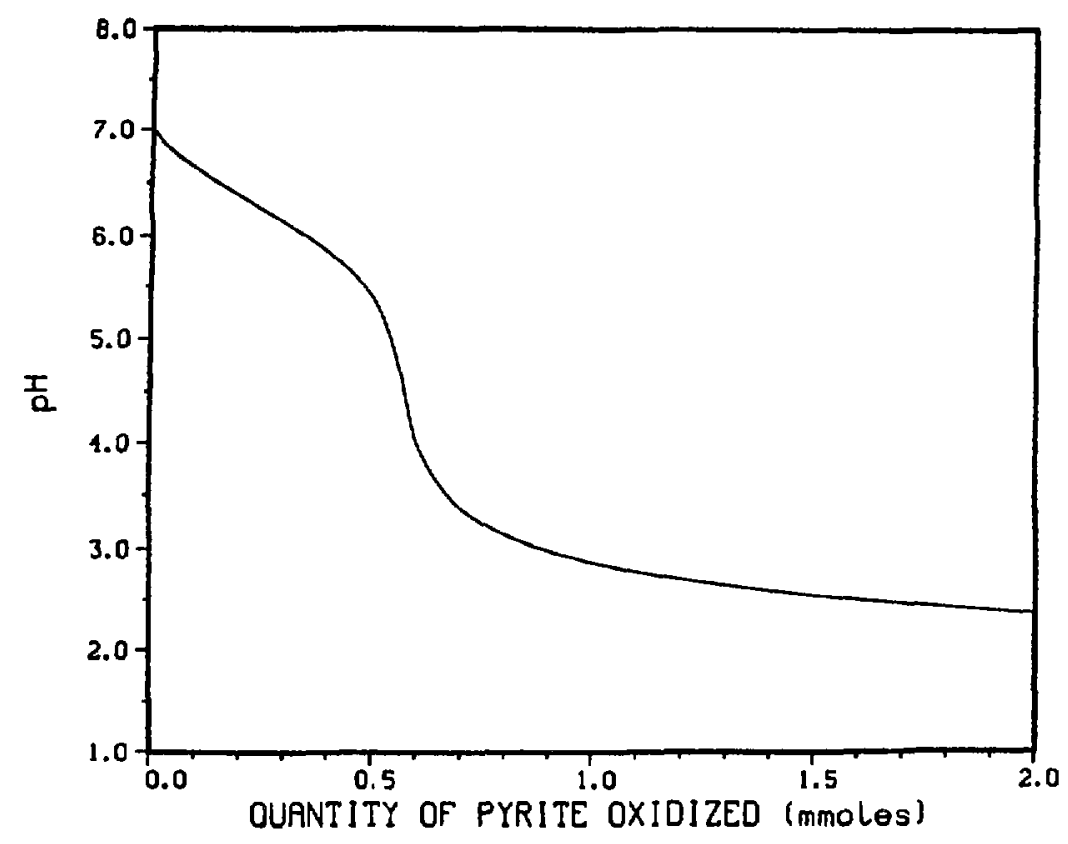

Fig. 7. The $\mathrm{pH}$ of Well J-13 water as a function of pyrite oxidation.

a smectite clay containing iron. Overall reactions for these processes can be written as

and

$$
4 \mathrm{FeS}_{2} \text { (pyrite) }+15 \mathrm{O}_{2} \text { (gas) }+8 \mathrm{H}_{2} \mathrm{O}=8 \mathrm{SO}_{4}^{2-}+16 \mathrm{H}^{+}+2 \mathrm{Fe}_{2} \mathrm{O}_{3} \text { (hematite), }
$$

$$
\begin{aligned}
& 12 \mathrm{FeS}_{2} \text { (pyrite) }+45 \mathrm{O}_{2} \text { (gas) }+12 \mathrm{SiO}_{2} \text { (aqueous or solid) }+22 \mathrm{H}_{2} \mathrm{O} \\
& +\mathrm{Na}_{2} \mathrm{Si}_{10} \mathrm{Al}_{2} \mathrm{O}_{24} \cdot 8 \mathrm{H}_{2} \mathrm{O}(\mathrm{Na} \text {-clinoptilolite }) \\
& =2 \mathrm{NaSi}_{11} \mathrm{AlFe}_{6} \mathrm{O}_{30}(\mathrm{OH})_{6}(\mathrm{Na} \text {-nontronite })+48 \mathrm{H}^{+}+24 \mathrm{SO}_{4}^{2-},
\end{aligned}
$$

where the sodium end members of clinoptilolite and nontronite were used to illustrate the reactions. In the reaction-path calculations, both clinoptilolite and nontronite were considered solid solutions. ${ }^{18}$ These reactions indicate that indeed 4 moles of $\mathrm{H}^{+}$are produced for each mole of pyrite 
oxidized with the reaction products predicted by the reaction-path calculations. Oxidation of about 0.5 mols/ $/$ of pyrite could be accommodated without large changes in $\mathrm{pH}$ (see Fig. 7). This would add 1 mmol/ $\ell$ of sulfate to the water, which would be a factor of 5 more than the normal Vell $J-13$ water content.

When the presence of local minerals is ignored, as it was in all the previous calculations, the buffering capacity of the water/mineral system will tend to be underestimated. This can be seen from the results of a number of reaction-path calculs:ions in which local minerals were assumed to be present in quantities sufficient to react with pyrite oxidation products. The interpretation of these calculations is complicated by the fact that the presence of the minerals will tend to shift the pH of We11 J-13 water slightly as they come to equilibrium with the water in the absence of pyrite oxidation. For this reason, two calculations were always done when local minerals were assumed to be prestnt: one calculation in which pyrite oxidation occurred and one in which no pyrite oxidation occurred. By comparing the results of the two calculations, the effect of $\mathrm{H}^{+}$produced by pyrite oxidation could be assessed. The local minerals were included in the calculation by adding them as reactants in addition to the pyrite to be oxidized.

Figure 8 shows a plot of $\mathrm{pH}$ as a function of moles of pyrite added to We11 J-13 water at $25^{\circ} \mathrm{C}$ for a calculation in which Na-clinoptilolite, K-clinoptilolite, and Ca-clinoptilolite were added at the rate of $2 \mathrm{mols} / \mathrm{mol}$ of pyrite, and cristobalite was added at the rate of 5 mols/mol of pyrite. Without pyrite oxidation, the water $\mathrm{pH}$ increases from 7 to 8.4. This result is consistent with previous reaction-path calculations of volcanic glass dissolution at Rainier Mesa. ${ }^{18}$ with pyrite oxidation, the $\mathrm{pH}$ remains essentially constant at 7 . The result in Fig. 8 can be compared with that in Fig. 7 , where no additional minerals were present. The stable $\mathrm{pH}$ is the result of buffering by clinoptilolite. The primary reaction products of the pyrite oxidation are nontronite and kaolinite. The overall reaction for this calculation can be written as

$$
\begin{aligned}
& 12 \mathrm{FeS}_{2} \text { (pyrite) }+45 \mathrm{O}_{2} \text { (gas) } \\
& +25 \mathrm{Na}_{2} \mathrm{Si}_{10} \mathrm{Al}_{2} \mathrm{O}_{24} \cdot 8 \mathrm{H}_{2} \mathrm{O} \text { (Na-clinoptilolite) }
\end{aligned}
$$




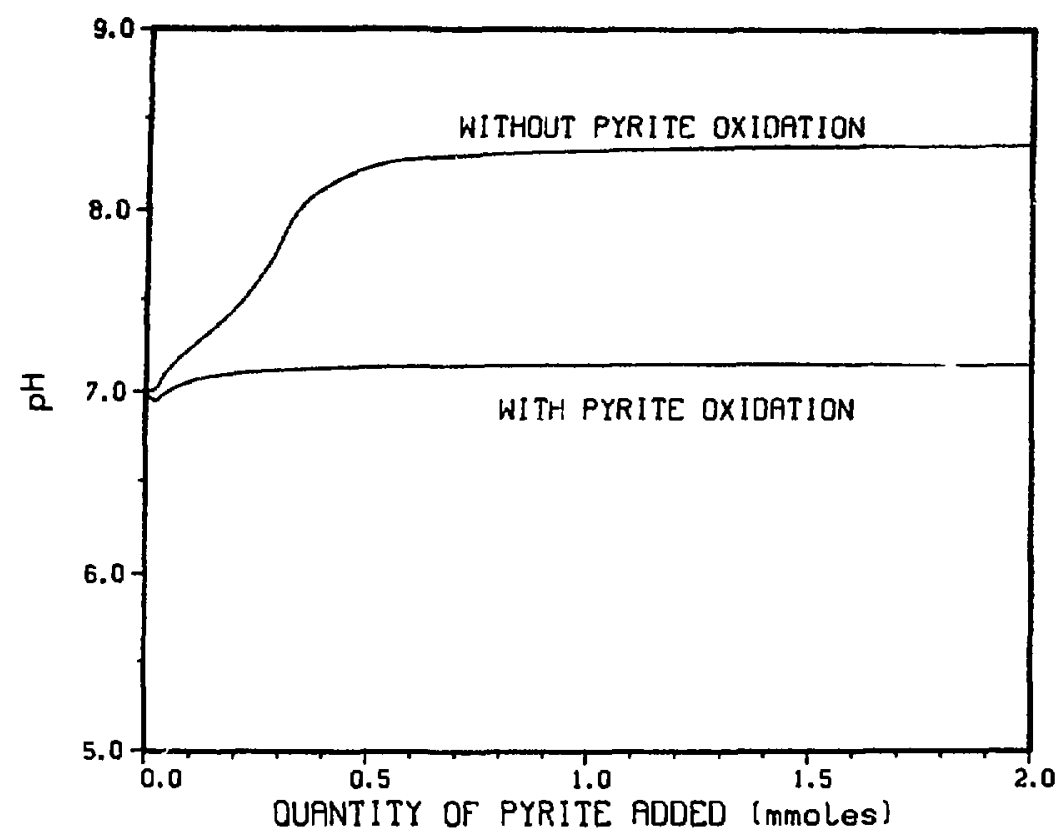

Fig. 8. The $\mathrm{pH}$ of We11 J-13 water as a function of pyrite and local mineral addition. Local minerals were $\mathrm{Na}$-clinoptilolite (2 mols/mol pyrite added), K-clinoptilolite (2 mols/mol pyrite added), Ca-clinoptilolite ( 2 mols/mol pyrite added), and cristobalite ( 5 mols/mol pyrite added).

$$
\begin{aligned}
& =48 \mathrm{Na}^{+}+2 \mathrm{NaSi}_{11} \mathrm{AlFe}_{6} \mathrm{O}_{30}(\mathrm{OH})_{6}(\mathrm{Na}-\text { nontronite })+180 \mathrm{SiO}_{2} \text { (cristobalite) } \\
& +24 \mathrm{SO}_{4}^{2-}+24 \mathrm{Al}_{2} \mathrm{Si}_{2} \mathrm{O}_{5}(\mathrm{OH})_{4} \text { (kaolinite) }+146 \mathrm{H}_{2} \mathrm{O},
\end{aligned}
$$

where the sodium end members of clinoptilolite and nontronite were used to lllustrate the reaction. In the reaction-path calculations, both clinoptilolite and nontronite were considered solid solutions. ${ }^{18}$ The overall reaction indicates that 2.08 mols of clinoptilolite are destroyed per mol of pyrite oxidized. In this calculation, excess clinoptilolite was available ( $6 \mathrm{mols} / \mathrm{mol}$ of pyrite oxidized). The overall reaction does not involve the production or consumption of $\mathrm{H}^{+}$; this is consistent with the stable pH seen in Fig. 8. The system is held on the clinoptilolite-kaolinite phase boundary at an aqueous silica activity in equilibrium with cristobalite as long as these solid phases are present, ${ }^{8}$ and this controls the $\mathrm{pH}$ of the water. 
A number of other reaction-path calculations involving the oxidation of pyrite were done with other minerals such as albite, potassium-feldspar, and anorthite present, with different mineral addition rates, and at other temperatures. The results with other minerals present are generally similar to the results presented In Fig. 8, so long as a sufficient quantity of minerals was available to react with pyrite oxidation products. As the quantity of additional minerals present is reduced, the pH of the water falls somewhere between the results shown in Figs. 7 and 8 . Although calculations assuming that volcanic glass is present have not been done for this work, other studies indicate that oxidation of pyrite in the presence of glass would produce similar results. 18 At $125^{\circ} \mathrm{C}$, beidellite replaces kaolinite as a reaction product, but the pH behavior is similar to that shown In Fig. 8 . Figure 9 shows a plot of $\mathrm{pH}$ as a function of mols of $\mathrm{NaOH}$ added to Well J-13 water with Na-clinoptilolite, K-clinoptilclite, and Ce-clinoptilolite added at the rate of 2 mols/mol of $\mathrm{OH}^{-}$and cristobalite at the rate of $5 \mathrm{mols} / \mathrm{mol}$ of $\mathrm{OH}^{-}$. Up to a level of about 2.3 mmols of $\mathrm{NaOH}$ added, the $\mathrm{pH}$ of the water is slightly higher than the $\mathrm{pH}$ of Well $\mathrm{J}-13$ water alone under the same conditions (compare Figs. 6 and 9). This is consistent with the previous conclusion: that the addition of these minerals tends to raise the $\mathrm{pH}$ of We11 $\mathrm{J}-13$ water to about 8.4 if nothing else occurs. For larger quantities of $\mathrm{NaOH}$ added, the $\mathrm{pH}$ of the water/mineral system is lower. The difference between the results with and without minerals present for $\mathrm{OH}$ - addition (Figs. 6 and 9) is not as dramatic as the difference in results for $\mathrm{H}^{+}$addition (pyrite oxidation). This indicates that the minerals do not make a large contribution to the buffering capacity for $\mathrm{OH}^{-}$addition.

The results presented here indicate that Well J-13 water alone or with the minerals commonly found in Yucca Mountain has a relatively good $\mathrm{pH}$ buffering capacity. This is particularly true for the water/mineral system that is subject to $\mathrm{H}^{+}$addition. However, these calculations have assumed equilibrium behavior. This is a valid assumption for reactions involving only aqueous species, but kinetic constraints may limit rates of aqueous-solid reactions such as precipitation or dissolution. If the buffering capacity of the water/mineral system becomes important, it may be nesessary to perform additional experiments or analyses to verify the assumption of nearequilibrium behavior. 


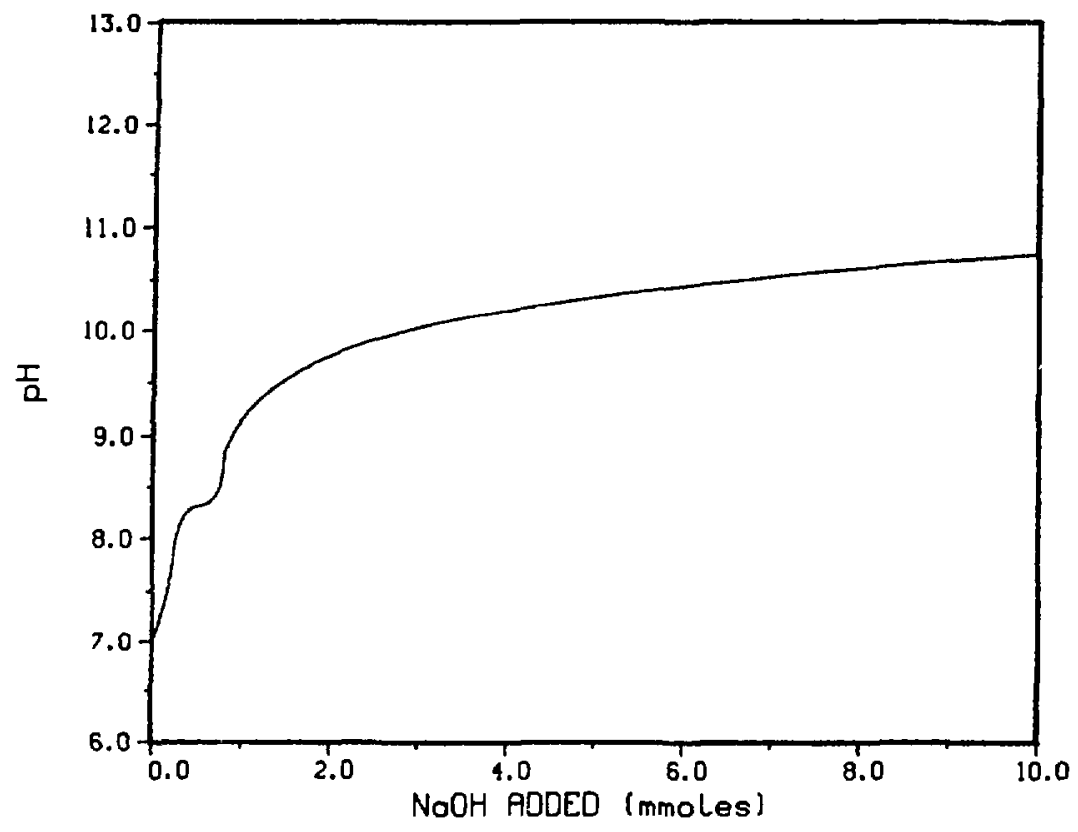

Fig. 9. The $\mathrm{pH}$ of Well $\mathrm{J}-13$ water as a function of $\mathrm{NaOH}$ and local mineral addition. Local minerals and addition rates are the same as those listed for Fig. 8 .

Water from Well J-13 is generally similar to water from other wells that tap the tuffaceous aquifer near Yucca Mountain. In particular, waters from We11s UE-25bł 1 and USW H-1, H-4, H-5, H-6, and G-4 are expected to have buffering capacities similar to those of Well J-13. Water from Well usW H-3 has a higher $\mathrm{pH}$ and higher carbonate content than We11 $\mathrm{J}-13$ water does; therefore, it would have a higher buffering capacity for $\mathrm{H}^{+}$addition.

\section{F. Uxidation-Reduction Buffering Capacity}

The oxidation-reduction potential of groundwater tends to decrease as water migrates along flowpaths from the surface downward. ${ }^{29}$ Rainfall and snow melt enter the soll cover in equilibrium with air and are, therefore, saturated with oxygen ( $E \mathrm{~h}>400 \mathrm{mV}$ ) and carbon dioxide. In the thin soil zone at the surface, the dissolved oxygen is generally thought to be removed by 
reduction with organic matter. The equation representing this reaction can be written

$$
\mathrm{O}_{2}(\mathrm{~g})+\mathrm{CH}_{2} \mathrm{O}=\mathrm{CO}_{2}(\mathrm{~g})+\mathrm{H}_{2} \mathrm{O}
$$

According to Stum and Morgan, 28 after all the oxygen is consumed, other oxidizing agents can produce a sequence of additional reactions. The reactions are listed below in decreasing order of oxidation-reduction potential necessary for the reaction to occur.

$$
\begin{aligned}
4 / 5 \mathrm{NO}_{3}^{-}+\mathrm{CH}_{2} \mathrm{O} & =2 / 5 \mathrm{~N}_{2}(\mathrm{~g})+\mathrm{HCO}_{3}^{-}+1 / 5 \mathrm{H}^{+}+2 / 5 \mathrm{H}_{2} \mathrm{O} \\
2 \mathrm{MnO}_{2}(\mathrm{~s})+\mathrm{CH}_{2} \mathrm{O}+3 \mathrm{H}^{+} & =2 \mathrm{Mn}^{2+}+\mathrm{HCO}_{3}^{-}+2 \mathrm{H}_{2} \mathrm{O} \\
4 \mathrm{Fe}(\mathrm{OH})_{3}(\mathrm{~s})+\mathrm{CH}_{2} \mathrm{O}+7 \mathrm{H}^{+} & =4 \mathrm{Fe}^{2+}+\mathrm{HCO}_{3}^{-}+10 \mathrm{H}_{2} \mathrm{O} \\
1 / 2 \mathrm{SO}_{4}^{2-}+\mathrm{CH}_{2} \mathrm{O} & =1 / 2 \mathrm{HS}^{-}+\mathrm{HCO}_{3}^{-}+1 / 2 \mathrm{H}^{+} \\
1 / 2 \mathrm{H}_{2} \mathrm{O}+\mathrm{CH}_{2} \mathrm{O} & =1 / 2 \mathrm{CH}_{4}+1 / 2 \mathrm{HCO}_{3}^{-}+1 / 2 \mathrm{H}^{+}
\end{aligned}
$$

The equations above are written in their simplest terms and do not state the exact organic composition or what mineral may contain the oxidizing agent. With the possible exception of the reactions involving $\mathrm{MnO}_{2}$ and $\mathrm{Fe}(\mathrm{OH})_{3}$, each of the above reactions may be biologically catalyzed.

As the sequence of reactions occurs, the oxidation-reduction potential of the groundwater becomes increasingly more negative. As noted earlier, this is important in manzing nuclear waste elements because some of the waste elements become less soluble as the Eh of the solution becomes negative and the waste elements are reduced to the +IV oxidation state.

Like pH buffering capacity, the Eh buffering capacity depends on the composition of the aqueous phase and the minerals in contact with the aqueous phase. After the oxidation-reduction potential of the groundwater has been set by the reactions discussed above, reduced species of minerals such as pyrite $\left(\mathrm{FeS}_{2}\right)$, magnetite $\left(\mathrm{Fe}_{3} \mathrm{O}_{4}\right)$, and ilmenite $\left(\mathrm{FeTiO}_{3}\right)$ that are in contact with the groundwater can maintain the oxidation-reduction potential (Eh) of the groundwater and oxidize or reduce waste elements in the groundwater.

There are a number of questions that must be answered or estimated in trying to arrive at the Eh buffering capacity of the system. 
(1) What parts of the sequence of oxidation-reduction reactions 1 isted above take place in the tuffs of Yucca Mountain and its recharge area? (both past and future)

(2) Where, when, and how extensively is the system being recharged?

(3) What are the flowpaths of the groundwater that ultimately will be found within and below Yucca Mountain?

(4) Are there reducing minerals in and "upstream" from Yucca Mountain, and if so, what are their locations and quantities?

(5) Does groundwater along the flowpaths contact the reducing minerals?

(6) Is a reducing environment necessary in performance-assessment calculations before a repository in Yucca Yountain can meet the requirements of 10 CFR 60 and 40 CFR 191 ?

Unfortunately, we do not have answers to most of these questions. The USGS is actively considering the definition of flow paths and recharge areas, which is necessary before answering questions (2), (3), and (5). Sandia Natinal Laboratories is developing methods for performance-assessment calculations; these calculations will answer question (6). Information relating to questions ( 1 ) and (4) is discussed below.

(1) The water from Well USW H-3 (Tahles I and IV) is the most reduced $(E \mathrm{~h}=-143 \mathrm{mV})$; it exhibits no detectable sulfide ion or oxygen and contains the least amount of nitrate ion. One can deduce from this information that at one time, probably at the end of the last pluvial, 20 conditions were suitable for reaction Eqs. (1) through (4) to take place, but the reactions did not proceed to the extent of yielding sulfide ion or methane. A similar occurrence might be expected during future pluvials. Our data (Tables I through IV), such as the higher nitrate and oxygen concentration in waters from other we11s, suggest that local recharge is taking place in the vicinity of the other wells outside Yucca Mountain and that reducing reactions in this juvenile recharge water are not now progressing through the sequence mentioned earlier.

(4) Caporuscio ${ }^{30}$ has estimated that the volume percentage of $\mathrm{Fe}^{2+}$-bearing oxides in the rocks of Yucca Mountain is between 0.16 and $0.33 \%$. Assuming that the tuff density is $2 \mathrm{~g} / \mathrm{cm}^{3}$, this volume percentage 
equates with 20 to 40 mols or equivalents of $\mathrm{Fe}^{2+}$ available per cubic meter of tuff if ilmenite $\left(\mathrm{FeTiO}_{3}\right)$ is the mineral. By comparison, Table X lists the mols and equivalents of multivalent waste elements in a $70000-\mathrm{MTHM}$ repository loading ${ }^{31}$ of spent fuel after 1000 years. If a11 the elements on Table $X$ were to be reduced, the total equivalent is $5.70 \times 10^{8}$; this would require 1.43 to $2.85 \times 10^{7} \mathrm{~m}^{3}$ of tuff containing 0.16 to $0.33 \%$ average spread of $\mathrm{Fe}^{2+}$ minerals. This amount of tuff is equivalent to a volume of $3-$ to $6-\mathrm{m}$ depth under the entire repository. Although the volume percentage of $\mathrm{Fe}^{2+}$-bearing tuffs is small, the buffering capacity for the waste elements is very large. However, there are two conditions attached to this statement: (a) the waste-containing water must come in contact with the $\mathrm{Fe}^{2+}$-bearing rocks so that the $\mathrm{Fe}^{2+}$ is available to react, and (b) the air in the repository is not an unlimited source of oxygen that is transported with the waste elements in the groundwater.

TABLE X

REPOSITORY LOADING AFTER 1000 YEARS

\begin{tabular}{|c|c|c|c|c|}
\hline Waste Element & Grams & Mols & Equivalents & Reaction \\
\hline $\mathrm{Np}$ & $9.93 \times 10^{7}$ & $4.19 \times 10^{5}$ & $4.19 \times 10^{5}$ & $V+I V$ \\
\hline $\mathrm{Pu}$ & $5.22 \times 10^{8}$ & $2.18 \times 10^{6}$ & $4.36 \times 10^{6}$ & $V I+I V$ \\
\hline Tc & $5.38 \times 10^{7}$ & $5.43 \times 10^{5}$ & $1.63 \times 10^{6}$ & $V I I+I V$ \\
\hline $\mathrm{U}$ & $6.70 \times 10^{10}$ & $2.82 \times 10^{8}$ & $5.64 \times 10^{8}$ & $V I+I V$ \\
\hline 0 t & & & $5.70 \times 10^{8}$ & \\
\hline
\end{tabular}

\section{G. Other Information}

Additional relationships among the compositional vartables of the wells listed in Tables I through IV are shown in Figs. 10 through 14. Figure 10 shows a plot of relative fluoride content $\left(\mathrm{F}^{-} /\left[\mathrm{F}^{-}+\mathrm{Cl}^{-}\right]\right)$as a function of relative sodium content $\left(\mathrm{Na}^{+} /\left[\mathrm{Na}^{+}+\mathrm{K}^{+}+\mathrm{Ca}^{2+}\right]\right)$. Although the data exhibit considerable scatter, there is a tendency toward higher relative fluoride 


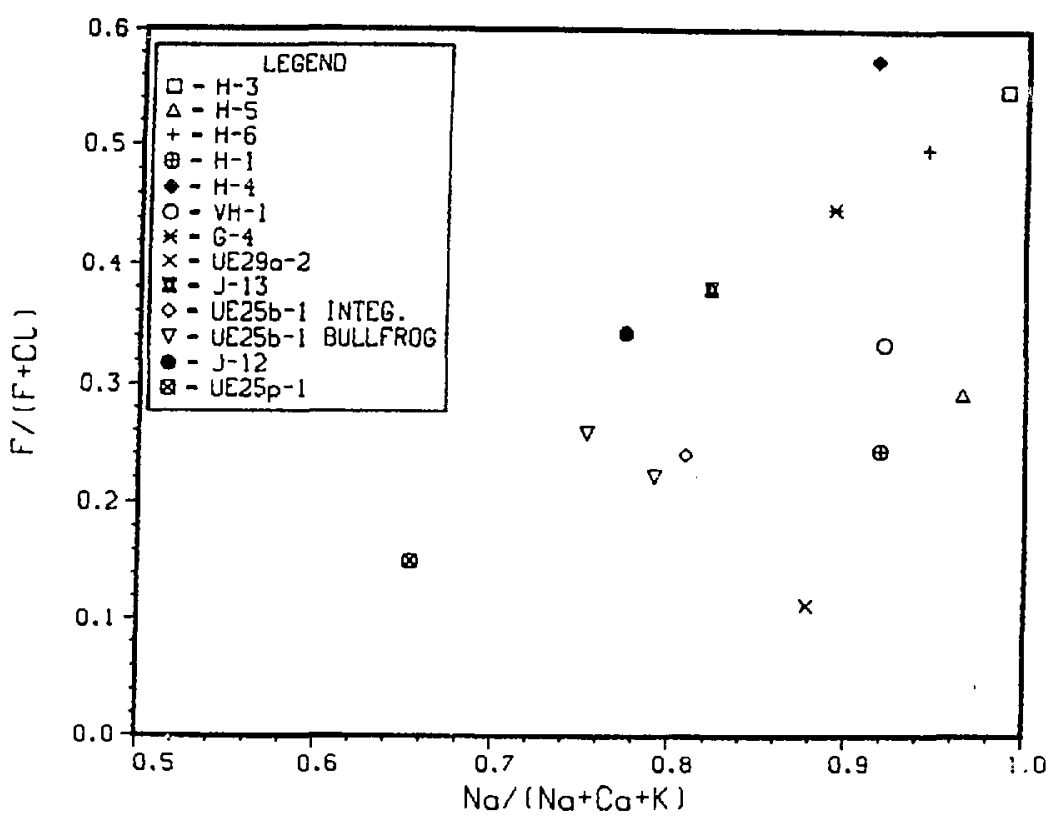

Fig. 10. Relative fluoride content as a function of relative sodium content for waters froin Yucca Mountain.

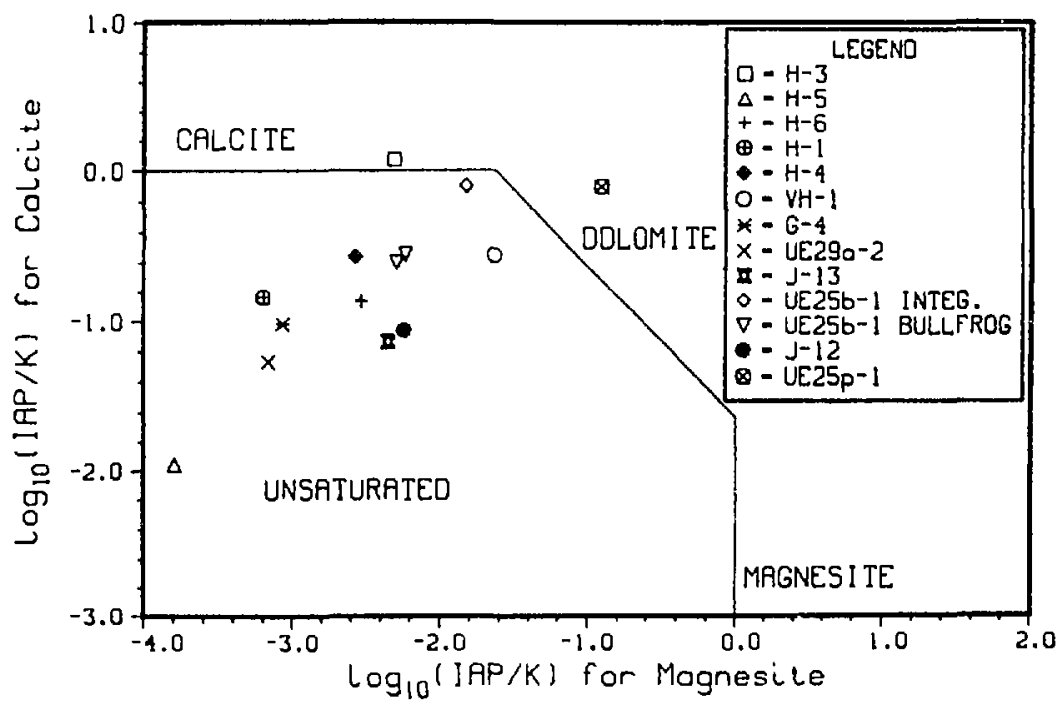

Fig. 11. Ratio of ion activity product to equilibrium constant for calcite as a function of the ratio for magnesite for waters from Yucca Mountain. The dolomite saturation line is also shown. 


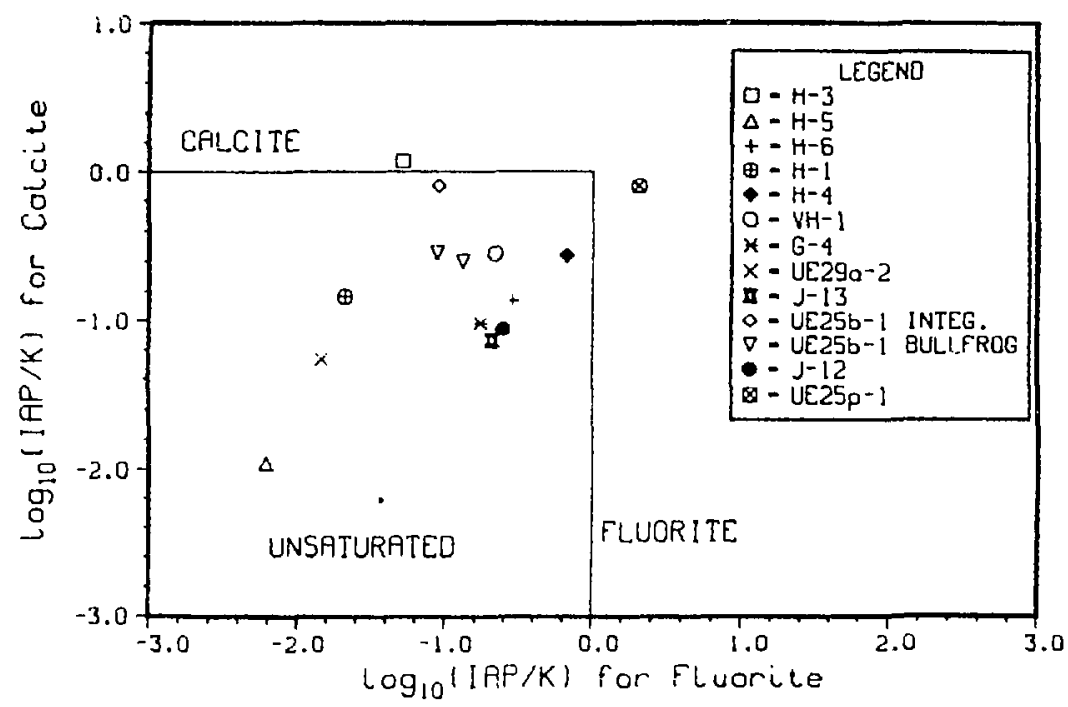

Fig. 12. Ratio of ion activity product to equilibrium constant for calcite as a function of the ratio for fluorite for water from Yucca Mountain.

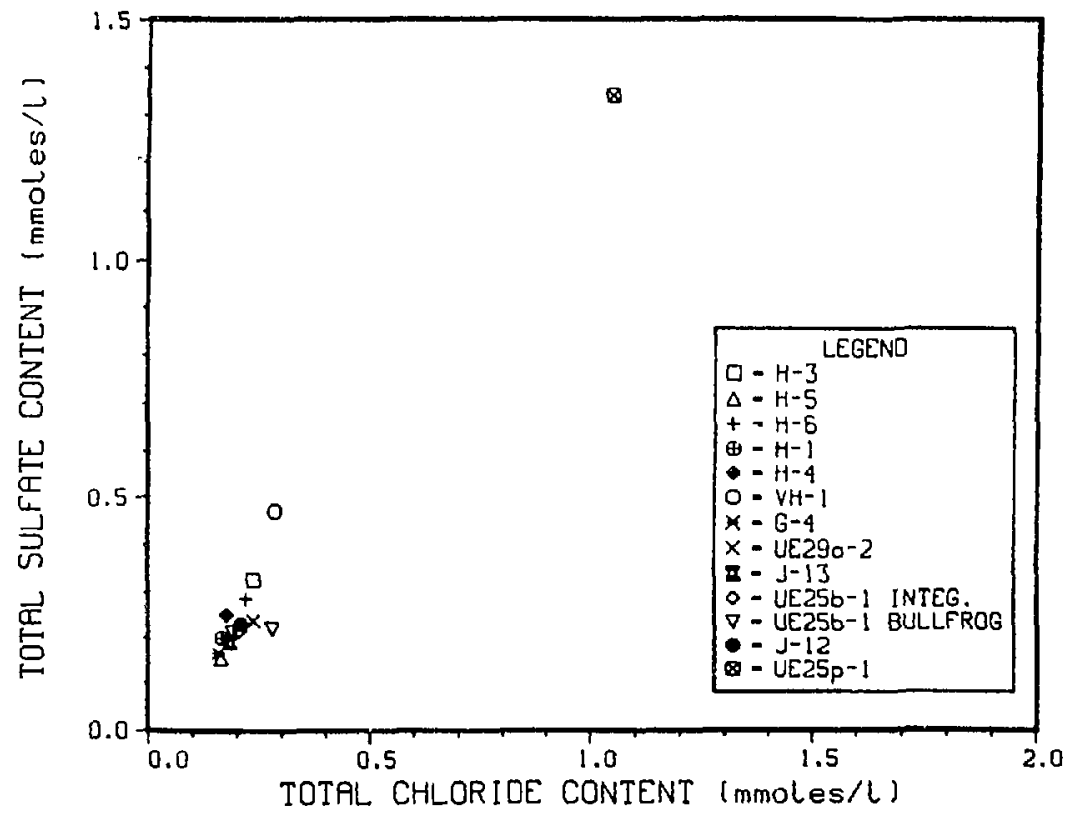

Fig. 13. Total sulfate content as a function of total chloride content for water from Yucca Mountain (see also Fig. 14). 


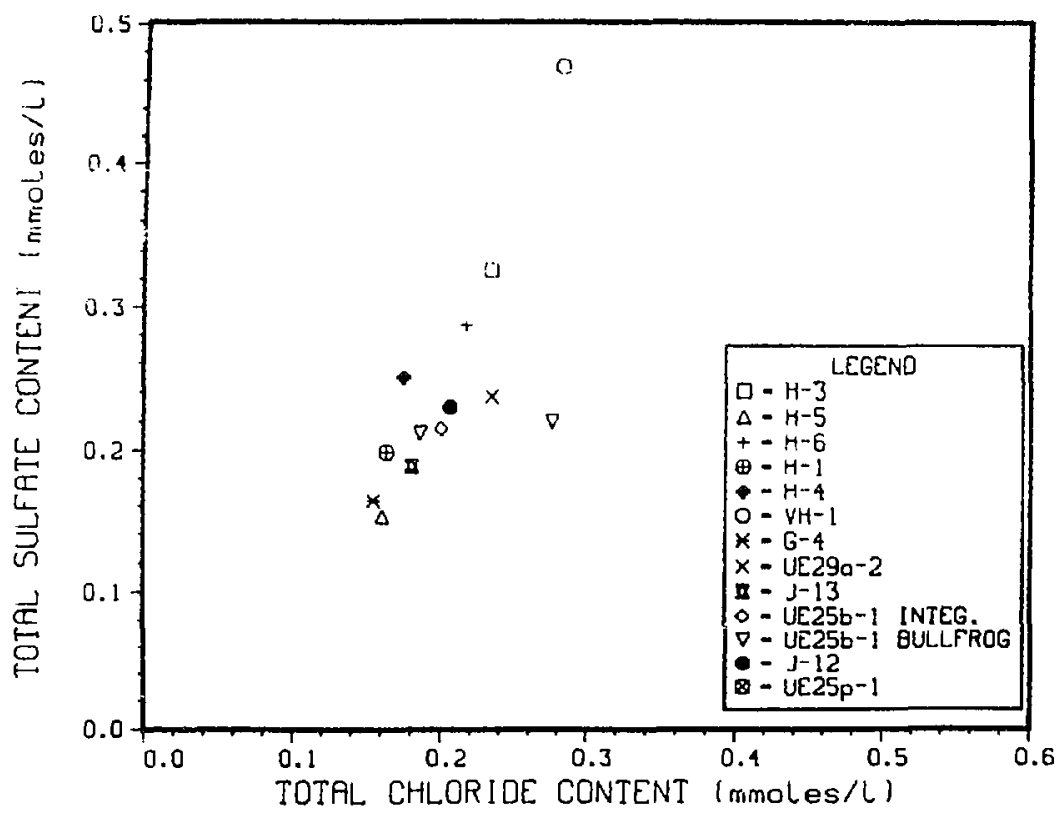

Fig. 14. Total sulfate content as a function of total chloride content for water from Yucca Mountain--expanded scale (see also Fig. 13).

content with increasing relative sodium content of the water. Because wells at Yucca Mountain and to the west have high relative sodium contents (see Fig. 2), they also tend to have higher fluoride contents. Fluoride complexation has some influence on waste-elsment solubility (see the Sec. IV.D). Most of the waters 1 isted in Tables I through IV are undersaturated with respect to calcite, dolomite, magnesite, and fluorite. Figure 11 shows a plot of the ion activity product divided by the equilibrium constant (IAP/K) for calcite, plotted as a function of IAP/K for magnesite $\left(\mathrm{MgCO}_{3}\right)$. The region where dolomite $\left[\mathrm{CaMg}\left(\mathrm{CO}_{3}\right)_{2}\right]$ is stable is also shown. For $\mathrm{IAP} / \mathrm{K}>1$ the water is supersaturated, whereas for $I A P / K<1$ the water is undersaturated. Waters from Wells USW $\mathrm{H}-3$ and UE-25b\#l (integral sample) are near saturation with respect to calcite; water from the carbonate aquifer (Well UE-25p非 1 ) is supersaturated with respect to dolomite. There is a tendency for high values of IAP/K for calcite to be associated with high values for magnesite. Figure 12 shows a similar plot of IAP/K for calcite as a function 
of IAP/K for fluorite $\left(\mathrm{CaF}_{2}\right)$. Water from Well UE-25pll 1 is supersaturated with respect to fluorite. As in Fig. 11, there is a tendency for high values of $\mathrm{IAP} / \mathrm{K}$ for calcite to be associated with high values for fluorite in Fig. 12. Figure 13 shows a plot of total sulfate content as a function of total chloride content for the waters listed in Tables I through IV. Most of the wells cluster in the low sulfate/chloride corner of the diagram; Fig. 14 shows an expanded plot of this portion of Fig. 13. The trend to increasing sulfate and chloride contents is similar to that observed by claassen for water from the Amargosa Desert. 20

Tables II, IV, and VI contain the analytical results for $\mathrm{NO}_{2}^{-}$and $\mathrm{NO}_{3}^{-}$--two anions that are normally not actively investigated except in surface or shallow water contamination problems. It is thought that $\mathrm{NO}_{3}^{-}$is usually introduced into the groundwater in surface recharge and is not a normal part of minerals; therefore, it may serve as a natural tracer for recharge along different pathways. Along some pathways, the organics and/or microbiological entities will reduce the $\mathrm{NO}_{3}^{-}$to $\mathrm{NO}_{2}^{-}$, to $\mathrm{N}_{2}$, and ultimately, to $\mathrm{NH}_{4}^{+}$. Under other circumstances of climate, etc., there may not be organics present and the $\mathrm{NO}_{3}^{-}$will appear in deep groundwater. The data in Tables II, IV, and VI may be useful in such modeling.

\section{CONCLUSIONS}

Assuming that the regional hydrology model of the USGS ${ }^{21}$ is correct, that general flow directions are southward in the vicinity of Yucca Mountain, and that the discharge area for the closed basin is the Amargosa desert, the following general conclusions can be drawn.

(1) The water below the repository site at Yucca Mountain has the same relative chemical composition as the recharge water from Pahute Mesa; it is predominantly a $\mathrm{NaHCO}_{3}$ water.

(2) In any direction away from Yucca Mountain (except north), the water composition in tuffaceous aquifers changes to higher relative calcium and magnesium concentrations and lower sodium. This progressive increase continues until its eventual discharge in the Amargosa desert.

(3) The water below the repository site is reducing $(-143 \mathrm{mV}$ vs hydrogen electrode). This $\mathrm{Eh}$ is sufficiently negative for the reduction of $\mathrm{PuO}_{2}^{2+}$ 
to $\mathrm{Pu}(\mathrm{IV}), \mathrm{NpO}_{2}^{+}$to $\mathrm{Np}(\mathrm{IV}), \mathrm{UO}_{2}^{2+}$ to $\mathrm{U}(\mathrm{IV})$, and $\mathrm{TcO}_{4}^{-}$to $\mathrm{Tc}(\mathrm{IV})$ after the elements have been eluted from the oxidizing environment of the repository. The reduced oxidation states exhibit the lowest solubilities. However, we do not presently know if the redox reactions will proceed or will be inhibited in some way.

(4) The natural organic content is very low in the groundwater. Consequently, the complexing and transport of waste elements with natural organic ligands is not a concern.

(5) The chemical composition of the groundwater can be modeled on the basis of the reaction of $\mathrm{CO}_{2}$-saturated infiltration water with glassy and devitrified tuffs.

(6) There is sufficient data for the groundwater compositions in the area Detween Yucca Mountain and the discharge locations in the Amargosa desert to adequately model the groundwater composition along the flow path, once the flow path is totally defined. The only data that may need reinforcement are the negative oxidation-reduction potentials below the repository site.

(7) The pil buffering capacity of the regional hydrology is determined by the $\mathrm{CO}_{2}$ dissolved in the recharge water, the biota at the ground surface, and the zeolites in the saturated zone. Under most circumstances, the $\mathrm{pH}$ should remain in the range of 6 to 8 .

(8) Four extremes or bounds of water composition for the area have been recognized from this work and the works of $\mathrm{Claassen}^{20}$ and White et al. 17

(a) $\mathrm{A} \mathrm{NatlCO}_{3}$ type of water from the reaction of $\mathrm{CO}_{2}$-saturated water with vitric (glassy) tuffs. Waters from Wells USW $\mathrm{H}-3, \mathrm{H}-5$, and H-6 are typical.

(b) Water with higher magnesium content and lower sodium content resulting from the reaction of $\mathrm{CO}_{2}$-saturated water with devitrified or crystaliine tuffs. In the area, there is no example of water thought to be solely derived from this reaction. However, of the wells listed in the tables of this document, Wells $\mathrm{J}-12$ and J-13 come closest to representing this water type.

(c) Water of the carbonate aquifer, which is derived from recharge waters ultinately equilibrating with the carbonate rocks of the paleozoic. Water from Well UE-25p\#l is representative. 
(d) Rain water or snow melt. The three waters mentioned above can be diluted by juvenile recharge.

The first three waters descrihed above are being used at los Alamos in sorption experiments and solubility experiments.

VI. FUTURE

There are still some unanswered questions concerning groundwater composition along possible flow paths to the accessible environment.

(1) Is the reducing groundwater found in the Tram Unit of Well USW H-3 distributed under the entire repository block? Pumping and analysis of water from the permeable zone in the Tram Unit (or lower) in We1ls USW H-5 or H-6 would help to answer this question. An alternative is to drill and pump a new well in the center of the exploratory block. These tests both involve pumping the packed-off zones in deep wells and are expensive. If, by using sensitivity calculations from performanceassessment analyses, it can be shown that the reducing conditions are not necessary for Yucca Mountain to meet the standards of $10 \mathrm{CFR} 60$ and $40 \mathrm{CFR} 19 \mathrm{l}$, the pumping tests will not be needed. Unfortunately, within the time frame of the Nuclear Waste Policy Act, both the testing and calculations may have to follow parailel paths.

(2) What is the oxidation-reduction buffering capacity of the water/mineral system now, and how will it vary in the future? From mineralogical studies, ${ }^{30}$ an estinate was made of the volume of reducing minerals in the tuffs below a repository in the Topopah Spring Member tuff and at selected locations along potential paths to the accessible environment. Although the volume per cent of reduced minerals is small, the overall amount within the site and available to the accessible environment is large. The unknown factors that cannot be evaluated at this time and that influence the occurrence of the reduced groundwaters are groundwater flow quantities, flow rates, directions or pathways, and probability of contact with the reduced minerals. In addition, there is scarce data about reducing minerals and/or organics along the upstream recharge flow paths under present day conditions or prospective pluvial 
conditions. Reducing conditions as found in Wells USW $\mathrm{H}-3$ and UE-25b\#l are present because of reactions that occurred in the past and should occur again unless climatic conditions are drastically different from those in the past. It is not possible to put bounds or extremes on the probability of occurrence.

(3) What is the $\mathrm{pH}$ buffering capacity of the water/mineral system in the future? Using estimates from USGS paleoclimate studies and estimated amounts of vitric and zeolitic tuffs in the recharge and Yucca Mountain area, one should be able to satisfactorily predict this result in a manner similar to that used in this report for pH buffering capacity.

(4) What is the magnitude or extent of waste elements that can be transported as (or with) particulates in the groundwater? A simplified plan of our approach was mentioned earlier in this report. We have initiated filtration studies on Well J-13 waters and will expand this work to include sorption measurements with the particulates. Long-term pumping tests on $U E-25 \mathrm{c}$ 非 $1,-2$, and -3 will also offer the opportunity for more filtration tests.

(5) Under what conditions, if any, are "thief" samples of groundwater representative of waters in equilibrium with the tuff strata from which the sample was taken? Wells USW $\mathrm{H}-4$ and $\mathrm{H}-6$, in which the USGS and Los Alamos propose to continue pump-testing the packed-off permeable zones, should first be sampled using a "thief" sampler. The analysis of the water should be carried out immediately in the field if possible. After these proposed pumping tests, "thief" samples should be taken at various depths and as a function of time up to 1 year or until the composition of the groundwater has stabilized. Froin these samplings a reasonable procedure can be evolved for taking meaningful "thief" samples. Each of the hydrology wells in the Yucca Mountain area could then be sampled and the waters analyzed. From the results, a composition vs depth and distance model could be developed.

(6) Do the calculations and laboratary experiments on solubility, sorption, fracture transport, and filtration of particulates represent actual processes and conditions of the Yucca Mountain repository site? USGS well-to-well pumping tests at UE-25c非1, -2 , and -3 could be used to answer this question. These three wells have been drilled $\sim 2000 \mathrm{~m}$ to the east of the repository block at Yucca Mountain near Wel1 UE-25p非; 
the USGS will use the pumping tests to determine the transmissivity and dispersion properties of the saturated tuffs. Los Alamos is formulating a proposal to be included as part of these tests, in which $9.5 \mathrm{~m}_{\mathrm{Tc}}$ and ${ }^{237} \mathrm{Pu}$ are used as tracers. These particular tracers have been selected for a number of reasons.

(a) They are isotopes of actual waste elements that will be present in spent fuels or reprocessed waste forms.

(b) The radioactivity will decay to innocuous levels in less than 2 years.

(c) Both ${ }^{95 m_{\mathrm{Tc}}}$ and ${ }^{237} \mathrm{Pu}$ are multivalent elements whose solubility and sorption are greatly affected by the oxidation-reduction conditions of the groundwater.

We believe these actual waste elements can safely be used in the tests and will yield results concerning the above question. In addition, naturally occurring isotopes such as the isotopes of uranium and thorium will be isolated from the groundwaters of the test. From the quantities and isotopes found, a model will be developed for retardation and transport of the uranium-thorium series of isotopes.

REFERENCES

1. L. V. Benson, J. H. Robinson, R. K. Blankenngel, and A. E. Ogard, "Chemical Composition of Ground Water and the Locations of Permeable Zones in the Yucca Mountain Area, Nevada," US Geological Survey open-file report USGS-OFR-83-854 (1983).

2. C. B. Bentley, "Geohydrologic Data for Test Well USW G-4, Yucca Mountain Area, Nye County, Nevada," US Geological Survey open-file report USGSOFR-84-063 (1984).

3. W. Thordarson, "Geohydrological Data and Test Results from Well J-13, Nevada Test Site, Nye County, Nevada," IS Geological Survey, WaterResources Investigations report 83-4171 (1983).

4. R. W. Craig, R. L. Reed, and R. W. Spengler, "Geohydrologic Data for Test Well USW H-6, Yucca Mountain Area, Nye County, Nevada," US Geological Survey open-Eile report USGS-OFR-83-856 (1983).

5. D. H. Lobmeyer, M. S. Whitfield, Jr., R. R. Lahoud, and Laura Bruckheimer, "Geohydrologic Data for Test Well UE-25b非, Nevada Test Site, Nye County, Nevada," US Geological Survey open-file report USGS-OFR-83-855 (1983). 
6. C. B. Bentley, J. H. Rnbinson, and R. W. Spengler, Geohydrologic Data for Test Wel1 USW il-5, Yucca Mountain Area, Nye County, Nevada," US Geological Survey open-file report USGS-OFR-83-853 (1983).

7. W. R. Daniels, B. R. Erdal, and D. T. Vaniman, Comps., "Research and Development Related to the Nevada Nuclear Waste Storage Investigations, July 1--Septenber 30, 1982," Los Alamos National Laboratory report LA-9577-PR (darch 1983).

8. K. Wolfsberg and D. T. Vaniman, Comps., "Research and Development Related to the Nevada Nuclear Waste Storage Investigations, October 1--December 31, 1983," Los Alamos National Laboratory report LA-10032-PR (August 1984).

9. W. R. Daniels, K. Wolfsberg, R. S. Rundberg, A. E. Ogard, J. F. Kerrisk, C. J. Duffy, et al., "Summary Report on the Geochemistry of Yucca Mountain and Environs," Los Alamos National Laboratory report LA-9328-MS (December 1982).

10. A. E. Ogard, W. R. Daniels, and D. T. Vaniman, Comps., "Research and Development Related to the Nevada Nuclear Waste Storage Investigations, October 1--December 31, 1982," Los Alamos National Laboratory report LA-9666-PR (May 1983).

11. A. H. Davis, Comp., "Los Alamos National Laboratory Quality Assurance Plan and Procedures for the Nevada Nuclear Waste Storage Investigation," Los Alamos National Laboratory report LA-9331-MS (in preparation).

12. K. Wolfsberg, W. R. Daniels, B. R. Erdal, and D. 'T. Vaniman, Comps., "Research and Development Related to the Nevada Nuclear Waste Storage Investigations, April 1--June 30, 1982," Los Alamos National Laboratory report LA-9484-PR (October 1982).

13. K. Wolfsberg, D. T. Vaniman, and A. E. Ogard, Comps., "Research and Development Related to the Nevada Nuclear Waste Storage Investigations, January 1--March 31, 1983," Los Alamos National Laboratory report LA-9793-PR (June 1983).

14. A. E. Ogard, K. Wolfsberg, and D. T. Vaniman, Comps., "Research and Development Related to the Nevada Nuclear Waste Storage Investigations, April 1--June 30, 1983," Los Alamos National Laboratory report LA-9846-PR (December 1983).

15. E. A. Bryant and D. T. Vaniman, Comps., "Research and Development Related to the Nevada Nuclear Waste Storage Investigations, July 1--September 30, 1983," Los Alamos Nationa1 Laboratory repurt LA-10NGo-PR (Ju1y 1984).

10. J. L. Means, A. S. Maest, and D. A. Crerar, "The Organic Geochemistry of Deep Groundwaters and Organo-Radionuclide Interactions at Hydro-Thermal Conditions," Office of Nuclear Waste Isolation report ONWI-448 (1982). 
17. A. F. White, H. C. Claassen, and L. V. Benson," The Effect of Dissolution of Volcanic Glass on the Water Chemistry in a Tuffaceous Aquifer, Rainier Mesa, Nevada," US Geological Survey Water-Supply Paper $1535-Q(1980)$.

18. J. F. Kerrisk, "Reaction-Path Calculations of Groundwater Chemistry and Mineral Formation at Rainier Mesa, Nevada," Los Alamos National Laboratory report LA-9912-MS (December 1983).

19. H. C. Claassen, "Water Quality and Physical Characteristics of Nevada 'Test Site Water-Supply Wells," US Geological Survey report USGS-474-158 (1973).

20. H. C. Claassen, "Sources and Mechanisms of Recharge for Ground Water in the West-Central Amargosa Desert, Nevada--A Geochemical Investigation," US Geological Survey open-file report USGS-OFR-83-542 (1983).

21. R. K. Waddel1, "Two-Dimensional, Steady-State Model of Groundwater Flow, Nevada Test Site and Vicinity, Nevada-California," US Geological Survey Water Resources Investigations 82-4085 (1982).

22. D. L. Hoover, "Genesis of Zeolites, Nevada Test Site," in Nevada Test Site, E. B. Eckel, Ed., Geol. Soc. Am. Mem. 110, 275-283 (1968).

23. H. C. Claassen and A. F. White, "Application of Geochemical Kinttic Data to Groundwater Systems, a Tuffaceous-Rock System in Southern Nevada," in Chemical Modeling in Aqueous Systems, E. A. Jenne, Ed., Am. Chem. Soc. symp. Ser. $93,771-793(1978)$.

24. A. C. Waters and P. R. Carrol1, Eds., "Preliminary Stratigraphic and Petrologic Characterization of Core Samples From USW-G1, Yucca Mountain, Nevada," Los Alamos National Laboratory report LA-8840-MS (November $1981)$.

25. F. Caporuscio, D. Vaniman, D. Bish, D. Broxton, B. Arney, G. Heiken, F. Byers, R. Gooley, and E. Semarge, "Petrologic Studles of Drill Cores USW-G2 and UE 25b-1H, Yucca Mountain, Nevada," Los Alamos National Laboratory report LA-9255-MS (July 1982).

26. G. K. Moncure, R. C. Surdam, and H. L. McKague, "Zeolite Diagenesis Below Pahute Mesa, Nevada Test Site," Clays Clay Miner. 29", 385-395 (1981).

27. T. J. Wolery, "Calculation of Chemical Eruilibrium Between Aqueous Solution and Minerals: The EQ3/6 Softwale Package," Lawrence Livermore Laboratory report UCRL-52658 (1979).

28. W. Stumm and J. J. Morgan, Aquatic Chemistry (John Wiley and Sons, 1981), pp. 469-472.

29. A. I. Germanov, G. A. Volkov, A. K. Lisitsin, and V. S. Serebennikov, "Investigation of the Oxidation Reduction Potential of Ground Waters," Acad. Sci. USSR, Moscow, Inst. Geol. Ore Deposits, Petrogr., Mineral., Geochem. (1958). 
30. F. A. Caporuscio, "Preliminary Estimate of the Buffering Capacity of Fe, Mn Oxides at Yucca Mountain With Respect to Eh," Los Alamos National Laboratory report (to be published).

31. A. G. Croff and C. W. Alexander, "Decay Characteristics of Once-Through LWR and LMFBR Spent Fuels, High-Level Wastes, and Fuel-Assembly Structural Material Wastes," Oak Ridge National Laboratory report ORNL/ TM-7431. 